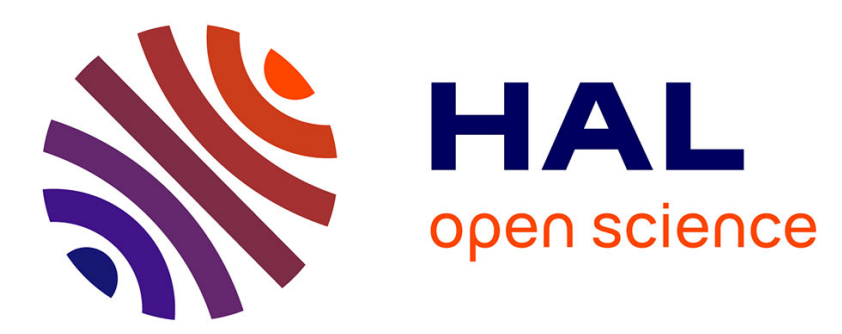

\title{
Does the presence of institutional investors in family banks affect profitability and risk? Evidence from an emerging market
}

\author{
Bowo Setiyono, Amine Tarazi
}

\section{- To cite this version:}

Bowo Setiyono, Amine Tarazi. Does the presence of institutional investors in family banks affect profitability and risk? Evidence from an emerging market. 2014. hal-01077118v2

\section{HAL Id: hal-01077118 \\ https: / hal-unilim.archives-ouvertes.fr/hal-01077118v2}

Preprint submitted on 19 Dec 2014

HAL is a multi-disciplinary open access archive for the deposit and dissemination of scientific research documents, whether they are published or not. The documents may come from teaching and research institutions in France or abroad, or from public or private research centers.
L'archive ouverte pluridisciplinaire HAL, est destinée au dépôt et à la diffusion de documents scientifiques de niveau recherche, publiés ou non, émanant des établissements d'enseignement et de recherche français ou étrangers, des laboratoires publics ou privés. 


\title{
Does the presence of institutional investors in family banks affect profitability and risk? Evidence from an emerging market
}

\author{
Bowo Setiyono $^{\mathrm{a} 1}$ and Amine Tarazi ${ }^{\mathrm{a}}$ \\ Université de Limoges, LAPE, 5 rue Félix Eboué, 87031 Limoges Cedex, France
}

This draft: October 23, 2014

Please do not quote without the permission of the authors

\begin{abstract}
This study aims to investigate whether the presence of institutional investors in family-controlled banks impacts their performance and risk. Using detailed data on Indonesian banks from 2001 to 2008 and controlling for various factors, our results first show that family-controlled banks are less profitable and more risky than other banks. Specifically, family presence, either under the form of direct ownership, pure single majority, or family directors, is related to higher default risk, income variability, and loan risk. However, the presence of institutional investors as a second stage block holder in family controlled banks tends to mitigate and even reverse such behavior by reducing risk-taking and improving performance. Our results are generally robust with regard to endogeneity issues and alternative specifications.
\end{abstract}

JEL classification: G21 G28 G32 G34

Keywords: Family bank, performance, risk, emerging market, second largest owner, family director

${ }^{1}$ Corresponding author. Tel: + 33555149251

E-mail address : bowo.setiyono@etu.unilim.fr (B. Setiyono) 


\section{Introduction}

A growing body of research highlights that banks as well as other businesses in many countries are controlled and owned by families (Brown and Dinç, 2005; Naldi et al., 2007; Pathan, 2009; Wright and Kellermanns, 2011). In Western Europe, for instance, the Wallenbergs family owns Sweden's largest bank, SEB and approximately $44 \%$ of European firms are controlled and ultimately owned by families (Faccio and Lang, 2002). In Latin America, Banco de Chile is controlled by the Luksic family and around $60 \%$ of the firms listed in the Bolse de Comercio de Santiago are family controlled firms (FCF) (Martínez et al., 2007). In Asia, families control more than $64 \%$ of the firms listed in the Hong Kong Stock Exchange. Thailand's largest bank is under control of the Sophonpanich family while in Indonesia many banks are largely controlled by several families particularly during Soeharto's presidency periods.

In most cases, a family is often the ultimate owner of a business group consisting of several to numerous firms whose shares are either privately or publicly held. There are two broad categories of family shareholdings. On the one hand, the controlling family directly holds the shares through one or several of its members and commonly assigns one of them on the board as a director (family director). On the other hand, it can also indirectly control the firm through other businesses as their arm lengths (the so-called ultimate owner). Many believe that the presence of families influences the decision making processes and therefore family firms are theoretically considered as different from their counterparts (Bammens et al., 2011; Miller and Le Breton-Miller, 2006). Because families' and family directors' reputations are linked to the firm, they have stronger willingness and motivation to commit their resources to keep the business running for future generations. Other studies, however, argue that the existence of owning families can adversely affect the firm performance and consider that family-controlled businesses (FCB) suffer from various problems such as a lack of professional management (Claessens et al., 2000; Schulze et al., 2003), expropriation of minority shareholders (Morck and Yeung, 2003), inadequate capital structure due to its growing number of family members (Chandler, 1990), and skepticism by financial markets (Claessens et al., 2002). 
Previous studies on family-owned businesses have shown mixed results (see, e.g., Bertrand and Schoar, 2006; Heugens et al., 2009; Jiang and Peng, 2011a; Liu et al., 2011; Pindado and Requejo, 2014; Villalonga and Amit, 2006). Some studies show that familycontrolled businesses tend to outperform their counterparts. This is in line with the conjecture that family controlled businesses allow the alignment of interest between parties specially when ownership stakes are being held by a large family (Anderson and Reeb, 2003; Demsetz and Lehn, 1985). On the contrary, some studies find family ownership to create an environment in which members can easily undertake opportunistic actions at the cost of other investors (Claessens et al., 2000). Others find that family ownership does not significantly impact performance (Barry et al., 2011; Jiang and Peng, 2011b). Alternatively, the link between family ownership and risk or performance might be attenuated or reinforced by environmental and business factors (the contingency perspective). For instance, Attig et al. (2008) find that the presence of large shareholders other than the controlling owner in East Asian emerging markets curbs the private benefits of the controlling owner as captured by reduced cost of capital. There has been, however, up to date little research on the impact of family ownership, in the presence of other large shareholders, in the banking sector.

To clarify the impact of family ownership on firms, Miller and Le Breton-Miller (2006) argue that it is crucial to firstly distinguish the type of family involvement (i.e., ownership without being directly involved in the management of the firm and direct involvement by appointing a family member as a director). Other authors emphasize the role played by the institutional environment of the firm in dealing with agency problems (Chung and Chan, 2012; Miller et al., 2011). In our study, the presence of family businesses in Indonesia can be traced for many decades but its increasing dominance started during the Suharto era and continues, although to a lesser extent, after the reformation period (post-1998). Unlike in Western countries, Indonesian firms, similarly to firms from other Asian countries, are often controlled by families (Claessens et al., 2000; Claessens and Yurtoglu, 2013) which mostly appoint their members to serve as directors. Because of poor investor protection, families can more easily expropriate minority shareholders than in other institutional environments. A survey by The Economist (1997) also highlights that the activities of family businesses in Indonesia during these periods largely involve social and political connections among the family tycoons, Suharto clan, and local companies. Such business practices, which also 
prevail in the banking sector, engender concerns such as asset-grabbing, lucrative monopolies, exclusive tax treatments, and financial back-up seeking in case of distress. Since previous studies provide conflicting results and the role played by family firms remains a unresolved puzzle (Bertrand and Schoar, 2006; Heugens et al., 2009; Liu et al., 2012), it is important to study the impact of family ownership of banks on bank performance and risk in an emerging market with unique structural and institutional features.

This study contributes the existing literature in several ways. First, while the large body of literature on bank ownership structure pays more attention on other characteristics, we offer evidence on what role family ownership plays in banks and specifically with regards to risk and performance. Given that previous studies on family businesses have largely focused on North American and European countries (see, e.g., Wright and Kellermanns, 2011 for an excellent survey) ${ }^{1}$, by focusing on an emerging country our aim is provide more insights with regards to cultural, political, and institutional characteristics. Claessens and Fan (2002) argue that although Asia is very diverse region in terms of economic development and institutional environment, it nevertheless exhibits specific corporate governance arrangements that are generic to other countries and most importantly the role of family ownership of firms ${ }^{2}$. Yet such issues have rarely been investigated regarding the Asian banking sector ${ }^{3}$. Second, we present evidence on how the type of control (direct versus indirect ownership) exerted by the controlling family affects risk and performance. As expropriation is more likely to occur in a country with weak investor protection (Claessens et al., 2000; Claessens and Yurtoglu, 2013; La Porta et al., 1999), we investigate the possible presence of expropriation through different types of control in Indonesia whose firms are largely family controlled. Third, we are able to distinguish cases where family control might be counterbalanced by the presence of multiple blockholders (i.e., family ownership combined with other institutional ownership) to further examine whether the presence of other important shareholders is likely to influence risk-

\footnotetext{
${ }^{1}$ Also, see, e.g., Anderson \& Reeb (2003) and Villalonga \& Amit (2006) for the non-bank U.S. firms, Maury (2006) for Western Europe.

${ }^{2}$ Joh (2003) studies non-financial firms listed on the Korean Stock Exchange and finds that firms' profitability is lower when the controlling family's ownership is lower. Bertrand et al., (2008) find that greater involvement by families in Thailand is related to lower performance. Boubakri et al., (2010) find that family in non-financial Asian firms leads to a higher equity premium due to the entrenchment.

${ }^{3} \mathrm{Lin}$ and $\mathrm{Wu}(2007)$ examine the case of families as shareholders of Taiwan's financial firms, but do not distinguish type of controls and deal with endogeneity while Bunkanwanicha et al., (2012) investigate how family/groupcontrolled banks in Thailand change their lending behavior across pyramidal tiers during distress periods.
} 
taking (monitoring and disciplinary role). Fourth, this study is able to examine the effect of family involvement through its appointed directors with the argument that the presence of family members on the board puts more pressure to serve the family's interests than those of other stakeholders. Morck et al. (2005) and Peng and Jiang (2010) contend that assigning family members on the board is a key strategic decision to ensure that each firm's direction is consistent with the goals of the family. Lastly, our study highlights the importance of corporate governance in the banking sector as addressed in the Basel accord (BIS, 2010) along with other bank prudential regulations. Hence, our results should provide guidance to bank regulators and supervisors in Asian emerging economies.

Our results show that family ownership has a significant impact on bank performance and risk. We further find that family ownership under its various forms has a negative impact on bank performance (i.e. return on assets, return on equity and risk-adjusted return) and a positive effect on risk, supporting the expropriation conjecture. Nevertheless, the presence of institutional investors in family-owned banks contributes to better performance and lower risk. The remainder of the paper is structured as follows. Section 2 discusses related literature and our research focus. Section 3 presents the Indonesian institutional setting and bank corporate governance. The data, variables, and econometric specification we use are discussed in section 4. Section 5 presents the results. Section 6 concludes.

\section{Related literature and research focus}

The literature on family-owned firms has primarily focused on agency theory. Under this view, Jensen and Meckling (1976), Fama and Jensen (1983) and Demsetz and Lehn (1985) argue that concentrated investors such as family owners have higher incentives to closely monitor firm managers and hence mitigate agency problems and maximize firm value. The presence of families as major shareholders and also as managers could furthermore be advantageous because there would be perfect alignment between the interests of owners and managers. In such a case, the performance of family firms would be higher than that of their counterparts. Families also need to consider longer term investments because they will pass their business to their succeeding generations (Casson, 1999; James, 1999).

In family firms, however, another type of agency problem can arise between minority and majority (i.e., family) owners who serve the potentially exploitative de facto agent (Morck 
and Yeung, 2003; Villalonga and Amit, 2006). The family interests might dominate over those of non-family (outside) shareholders (tunneling hypothesis). Hence, the controlling family has a negative influence on firms' performance (e.g., Filatotchev et al., 2005; Morck et al., 1988). In the same vein, other authors assert that controlling shareholders including families could extract private benefits from the firm as well as pursue different objectives as compared to those of minority shareholders (Anderson et al., 2009, 2012; Shleifer and Vishny, 1997). Likewise, DeAngelo and DeAngelo (2000) argue that the expropriation occurs through excessive compensation and perquisites, related-party transactions, or special dividends that can easily emerge in family firms.

Such expropriation should be more pronounced when the country has a weak investor protection (Claessens and Fan, 2002). Apart from this, family characteristics may be detrimental for the value-enhancing goal of firms. For instance, family-controlled firms are very vulnerable to family conflicts and coordination problems leading to ineffective management (Arregle et al., 2007).

Studies on family firms also seek further explanations based on stewardship theory. This theory posits that leaders (e.g., family directors) are not simply self-serving individuals, but are emotionally linked to the family and highly committed to the benefit of the organization and the owning family (Davis et al., 1997; Miller and Le Breton-Miller, 2006). Family members focus primarily on running the business for the interest of the family and have therefore a greater incentive to follow the family's direction and do not necessarily require close monitoring (Cruz et al., 2010). Gomez-Mejia et al. (2001) argue that a family member, who is also considered to have personal, emotional, and historical attachment to the firm, will prioritize the collective interest of all members over her/his personal interests because she/he perceives greater utility in cooperative behavior, which positively contributes to the firm performance. Hence, this theory predicts that family firms will outperform their counterparts as supported by previous studies (Hoopes and Miller, 2006; Villalonga and Amit, 2006).

The arguments above highlight that the owning family is a key aspect of corporate governance mechanisms (Anderson et al., 2012; Anderson and Reeb, 2003), distinguishing governance practices between family firms and non-family firms (Anderson and Reeb, 2004; Miller and Le Breton-Miller, 2006). More importantly, the type and the extent of family 
control and involvement in the firm will determine monitoring incentives, strategic behavior, performance and risk.

Whilst the empirical evidence on the relationship between family ownership and performance in the banking sector is very limited, there are even fewer studies on the relationship between family ownership and bank risk (Lin and $\mathrm{Wu}, 2010$ ). Studies by Naldi et al. (2007) and Barry et al. (2011) find that family-controlled businesses generally exhibit lower risk than non-family businesses. In contrast, Villalonga and Amit (2006) suggest that family-owned firms show higher risk, both systematic and idiosyncratic. Agency-based literature generally concludes that in emerging countries family businesses have a strong incentive to distort information in order to extract private benefits (Anderson et al., 2009; Chin et al., 2006; Lang et al., 2004). Shareholders might hence find it difficult to assess business values and performance since the quality of information is questionable (Fan and Wong, 2002). Hence, information distortion in family-controlled banks leads other investors to require higher returns (i.e., above-average rate of returns) regardless of the actual risk due to a higher perceived uncertainty. Considering that any choice will produce similar required returns, the controlling family might choose to take higher risk. Hence, it is argued that family ownership in an emerging economy such as Indonesia is positively associated with bank risk.

Further, previous literature argues that families can exert and/or reinforce their control over firms through pyramids that allow them to use one firm to control another firm with small direct investment (Claessens and Yurtoglu, 2013; La Porta et al., 1999). Such evidence is more pronounced in Asian firms compared to those in Western countries. Claessens et al. (2000) document that firms in Indonesia and Thailand are largely family-controlled with voting rights frequently exceeding cash flow rights, suggesting that pyramidal structures are prevalent. Such arrangements crucially influence the family's ability and incentive to expropriate minority shareholders (Claessens et al., 2002). In other words, indirect control by a family can differently affect firm performance, as opposed to direct control, because the family's interests are served through control chains with weaker scrutiny by management.

Families are presumably prone to private benefit extraction, particularly in a civil law country and/or a less developed institutional environment, if they are not monitored by other large shareholders (see, e.g., Claessens et al., 2000; Sacristán-Navarro et al., 2011). Fama and 
Jensen (1983) argue that the standard owner-manager conflict does not apply to a large proportion of family firms. They argue that the family often acts as both the principal, in the sense that it invests its wealth, and as the agent to protect its own interests through its representative which in turn leads to conflicts between the family and other minority investors (owner-owner conflict).

Laeven and Levine (2008) highlight that publicly listed firms with multiple blockholders in Western Europe have a different market value than widely held firms or firms with a single large owner. They further report that blockholders are less likely to cooperate and form coalitions when they are of different types (family, government, and institutional investor). Hence, firms can benefit from the presence of multiple large owners of different types and their mutual monitoring roles. Attig et al. (2008) argue that the failure to consider blockholders beyond the largest controlling owner in previous studies reflects the assumption that only the former represents a homogenous group with the rest of the shareholders having little incentive to monitor the firm. However, such blockholders may play a significant role because they can collude with others or even compete for corporate control. Using a sample of firms from eight East Asian countries Attig et al. (2008) find that the presence of multiple large shareholders, beyond the largest shareholder, significantly reduces the cost of equity which in turn increases the firm value, ceteris paribus. They document that the governance role played by other large shareholders is relatively more valuable in East Asia where complex ownership structures potentially embed more severe agency conflicts. The benefit brought by the presence of a second large owner is also supported by Lehmann and Weigand (2000) who find that the existence of a second large shareholder is related to higher profitability for German firms.

Hence, the domination of the family's interests therefore might need to be balanced with an ownership structure that limits the family's discretions over firm resources and possible expropriation. A second large shareholder has higher incentives to professionally monitor and discipline the firm, and prevents further opportunistic behavior by the family which in turn might affect performance and risk differently (Anderson et al., 2003; Attig et al., 2008; Claessens and Yurtoglu, 2013; Laeven and Levine, 2008; Lehmann and Weigand, 2000).

With regard to family involvement on the board, the owning family can assign directors to serve its interests and to actively participate to daily activities (active involvement). 
Empirically, family firms' boards in South and East Asia are mainly dominated by their members and nominees (Filatotchev et al., 2005). In line with this, Anderson and Reeb (2003, 2004) argue that the presence of family directors reduce information asymmetry and agency problems between the directors and the family since they will place the family's interests over their personal interests. Similarly, the resource-based theory pinpoints the advantages of having family directors (Barney, 2001). Unlike outside directors, family directors share common identity, loyalty, and trust. Such characteristics are highly valuable and hard-to-imitate competitive advantages (Chu, 2009; Habbershon and Williams, 1999; Liu et al., 2011; Luo and Chung, 2005). Further, family directors often fill the institutional voids to overcome market inefficiency particularly in emerging countries (Chakrabarty, 2009; Lee et al., 2008).

In contrast to the argument above, an active involvement by the owning family, through the appointed directors, can nevertheless distort the board's independence particularly in delivering objective judgments and preventing earnings management (Xie et al., 2003). Furthermore, Wright and Kellermanns (2011) suggest that board comprising family and nonfamily members engender an important issue; the family directors, for instance, may meet informally without involving non-family directors. In some cases, family directors outnumber non-family members leading to the dominance of family members. In addition, when family members hold positions on the board, firms bear the costs of excluding more capable and talented outsiders (Giovannini, 2009). Therefore, firms are exposed to higher risk of adverse selection and moral hazard. Based on the arguments above, the presence of family directors (i.e., active involvement) could be either detrimental or positive for firm performance.

Regarding risk taking behavior for banks with family directors, on the one hand there may be a higher perceived risk by outside shareholders who will face difficulties in monitoring and disciplining underperforming family directors (Morck and Yeung, 2003; Schulze et al., 2003). Specifically, Miller and Le Breton-Miller (2006) argue that the presence of family directors without strong outside monitoring not only induces expropriation but also gives more discretion to engage in risky behavior. On the other hand, family directors have higher incentives to secure the family's interests. For this reason, they are more likely interested in longer-term investments from which they get economic benefits 
that in turn will be passed onto the next generations (Casson, 1999; James, 1999). Under this view, family directors may prefer lower risk investments to secure the firm in the long run. Hence, the appointment of family directors can affect risk in both directions. Nevertheless, as argued above, the presence of a second large shareholder, such as an institutional investor, might influence the firm's strategic decisions and risk-taking.

\section{The Indonesian institutional setting and bank corporate governance}

Indonesia has experienced a substantial economic growth until the 1997 financial crisis hit South East Asia. The crisis called for the review of the existing corporate governance characteristics such as a very high degree of ownership concentration by family/business groups (e.g., Claessens et al. (2000) note that $71.5 \%$ of listed companies are owned by a family/business group), an excessive government-led growth (Hanazaki and Liu, 2007), lack of transparency and control (Zhuang et al., 2000), and poor investor protection (Obata, 2003). Many firms and banks in the country are owned by the few richest families, and highly connected to the ruling political parties. For instance, Fisman (2001) finds that Indonesian firms were largely politically connected to the ruling party and that their stock prices were very sensitive to the health reports of former President Suharto. Most of the sample firms were found to be owned by Suharto's allies such as Bob Hasan (Nusamba Group), Liem Sioe Liong (Salim Group), and Prajogo Pangestu (Barito Pacific Group) and affiliated with President Suharto's children (Bimantara and Citra Lamtoro Groups). This study concludes that politically dependent firms, on average, incurred more losses during the periods of increasing threat to Suharto's health than less-dependent firms. In such an environment, the banking sector was highly vulnerable due to the over reliance of firms on external funding leading to higher credit risk. In addition, ineffective supervision due to the characteristics of

the two-tier board system has been considered as one important factor behind the crisis (Zhuang et al., 2000).

During 1997, Central Bank of Indonesia (BI) was authorized to provide emergency loans to banks suffering from critical liquidity and bank run problems due to the deterioration of public confidence. Besides, this scheme was not fully successful since it was frequently conducted on an ad-hoc basis without predetermined mechanisms and adequate transparency. An explicit limited deposit guarantee (i.e. up to Rp20 millions per account of deposits) was 
introduced at the end of 1997 but this failed to prevent further bank runs. In January 1998, the government of Indonesia (GoI) introduced a blanket guarantee that covers all commercial banks' liabilities in all currency denomination. Along with improving financial stability and public confidence, the coverage of deposit insurance was revised to cover up to Rp5 billions (limited guarantee) in 2006, Rp1 billion in the beginning of 2007 and reduced to Rp100 millions in the middle of 2007, but again increased up to Rp2 billions in 2008.

In 1999, the Government of Indonesia (GoI) set the regulation (Regulation No. 28) on merger, consolidation, and acquisition for the banking sector, allowing more individual and institutional investors including foreigners to participate as owners. Such a regulation aimed to improve banks' capital standards and performance that severely deteriorated during the financial crisis. Another goal was to prevent excessive ownership concentration that could potentially harm minority owners and public interest. In the post-crisis period (1997-2000) 61 banks were closed, 54 were taken-over, and 39 recapitalized. Accordingly, in October 2004 Bank Indonesia set a regulation, the so-called single presence policy (PBI No. 16/2006), in order to strengthen the banking system, improve economies of scale, and promote effective bank supervision. This regulation stipulates that a controlling owner (i.e., either individual, institutional, direct or indirect) can only be the controlling owner in one bank. As a consequence, a shareholder that controls more than one bank has to adjust by either (1) selling the shares of the other bank(s) to new investors or (2) acquiring the other bank(s) or (3) establishing a bank holding company. This regulation does not apply for foreign banks and joint venture banks.

In the meantime, BI has introduced several regulations in order to promote good corporate governance particularly in the banking sector such as imposing a fit and proper test on bank board members, requiring a compliance director, and the introduction of independent board members. However, the implemented rules have not limited the number of family members sitting on the board allowing families to still exert their power through either direct or indirect control. The prevalence of owning families can be observed in most business groups. Approximately $87 \%$ of the banks in our sample, for instance, belong to both families and business groups. Only around $13 \%$ of non-family controlled banks belong business groups. This characteristic potentially entices controlling families to engage in expropriation activities (tunneling hypothesis) or otherwise to prop up the banks and other firms in the 
groups. By regulation, an independent board member is a person that is not allowed to have such a relationship (i.e. familial relationship) with the controlling shareholders. In addition, the circular letter of Bank Indonesia (No. 9/12/DPNP/2007) specifies that the president director (CEO) needs to be independent from the controlling family. In other words, a family can place its directors in positions other than president and independent directors. However, banks need to declare any familial relationship between the board members and shareholders as stipulated by the Bank Indonesia Regulations (No 8/4/PBI/2006 and PBI 8/14/PBI/2006). Hence, banks are also required to annually disclose all circumstances in which a potential conflict of interests could arise between the members of the board of directors, board of supervisors, and top management.

\section{Data, variables, and empirical setting}

\subsection{Sample}

The sample of this study consists of Indonesian banks namely regional development banks, state-owned banks, domestic private banks, foreign-owned banks and joint venture banks. We exclude rural banks and Islamic banks because of their small share in the banking industry, (1.39\% and $2.11 \%$ respectively).

Most of our data is extracted from banks' annual reports, banks' web sites, the data directory service of Indonesian Banking Institutes, news releases, and other relevant sources. We gather financial indicators as well as the name of board directors and board commissioners. Particularly, we identify the family and its members who hold the ownership through direct or ultimate ownerships (pyramidal structure), and track if the family appoints its member(s) to serve as the director on the board. To identify ultimate ownership, as in previous studies (see, e.g., Claessens et al., 2000; Faccio and Lang, 2002; La Porta et al., 1999; Maury, 2006; Pindado et al., 2014), we often have to gather information on affiliated firm's reports. It is very common that the children's family names in Indonesia are different from the parents' family names and we therefore pay a lot of attention when gathering the family members. When such data is not available in banks' annual reports or web sites, we seek information on familial relationship from marriage ceremonies or funeral services announced in available publications and news. In other cases, particularly for banks which are owned by business groups, we are able to collect more detailed profiles of family 
members and directors in the affiliated firm's report/websites or from banking magazines and newspapers that publish bankers' profiles including information on their families. We also retrieve data from available on-line services to verify or to complete the previous ones. We end up with 105 banks that contribute to $97.6 \%$ of the aggregate assets of the Indonesian banking system during the 2001-2008 period.

\subsection{Measurement of Variables}

\subsubsection{Measuring performance and risk}

This study uses several proxies to measure bank performance and risk. First, we consider the return on assets (ROA) that is defined as net income divided by total assets. Secondly, we use the return on equity (ROE), defined as net income divided by total equity. Both ROA and ROE are commonly used to measure performance. These proxies might not fully reflect the returns that compensate for each unit of risk. We hence utilize risk-adjusted returns which are defined as ROA or ROE divided by their respective standard deviations calculated from the last three observations for the respective years (i.e., $t, t-1$, and $t$-2). Regarding risk taking, we use two main measures namely the standard deviation of ROA (SDROA) and the standard deviation of ROE (SDROE). Calculations for both standard deviations are based on the last three observations for the respective year (i.e., $t, t-1$, and $t$ 2). Additionally, we also use the ratio of non-performing loan to gross loans (NPL) to measure bank loan risk. To measure default risk, we use Z-score (ADZP) as in Goyeau and Tarazi (1992), Lepetit et al. (2008) and Barry et al. (2011) which is defined as follows:

$$
\mathrm{ADZP}=\frac{\text { awerage ROA }}{\text { SDROA }}+\frac{\text { average equity to total assets }}{\text { SDROA }}
$$

where the first term represents bank asset risk, named ADZP1and the second measures leverage risk, named ADZP2.

\subsubsection{Family ownership and control variables}

The main variable of this study is family ownership (Family). This variable takes the value of one if the largest controlling shareholder is a family holding at least $10 \%$ of the control rights either through direct ownership (including individual family members) or through its affiliated firms (ultimate ownership). Otherwise, the variable is equal to zero. La 
Porta et al. (1999) argue that in many emerging economies large control stakes are not unusual and therefore minimum thresholds for family ownership are common in the literature. Considering a threshold of $10 \%$ is common in the literature (see, e.g., Claessens et al., 2000; Faccio and Lang, 2002; La Porta et al., 1999; Maury, 2006; Pindado et al., 2014). It is assumed that such shareholders have an effective control of the firm. In a pyramidal structure a family can be the ultimate owner of a firm without directly holding at least $10 \%$ of its shares. For example, if a family owns $40 \%$ of the shares of firm A, which owns $30 \%$ of firm B, which in turn owns $10 \%$ of bank $\mathrm{C}$, the family ends up with $10 \%$ of the control rights of bank $\mathrm{C}$. For robustness considerations we also examine how the results are affected by imposing a threshold of $25 \%$ which is the one used by Indonesian regulatory authorities to define the controlling owners regardless the form of the ownership.

We then segregate the type of control into several categories. First, direct control (Fam_direct) is a dummy variable equal to 1 when the family including all its members has a direct ownership of at least 10\%, and zero otherwise (Claessens et al., 2000; Claessens and Yurtoglu, 2013; La Porta et al., 1999). Alternatively, we consider a dummy that takes the value of one if the family indirectly controls the bank (i.e., through a pyramidal structure) and report the results in the robustness section. Second, to examine the impact of a family as the only controlling shareholder we use a dummy of one if the family controls the bank solely (Family_only) with no other shareholders or institutions controlling the bank, at our threshold of either $10 \%$ or $25 \%$. Third, as discussed previously, the second largest owner, particularly an institutional investor, has strong incentives to monitor and discipline the bank, to prevent opportunistic behavior by the family. To account for such an effect we set a dummy variable (i.e., Family_with_inst) that takes the value of one if both a family and an institutional investor have, each, an ownership of at least $10 \%$ and zero otherwise. As argued above, the presence of such multiple shareholders may allow for cross-monitoring of each other, reducing expropriation and/or mitigating excessive risk taking (Attig et al., 2008; Claessens and Yurtoglu, 2013; Laeven and Levine, 2008).

\subsubsection{Control variables}

We include several plausible variables influencing the dependent variables based on previous literature. Many argue that political connections play a significant role in the firm 
business (Claessens et al., 2008; Francis et al., 2009; Goldman et al., 2009; Liang et al., 2013). Firms with frequent government deals would place a high value on directors with the ability to influence government decisions (Adams et al., 2010). Such firms will hence likely appoint board members with political background (Agrawal and Knoeber, 2001). In Asia, Fisman (2001) finds that political connections are very important for firms' performance and more generally for the economy as a whole in a country like Indonesia. Nys et al. (2014) observe that politically connected banks in Indonesia are able to attract deposits more easily than their non-connected counterparts. Other studies also find the importance of political connections with regard to performance and risk (Carretta et al., 2012; Gul, 2006; Johnson and Mitton, 2003). Following Francis et al. (2009) and Nys et al. (2014), we consider the effect of political connections in family banks by introducing a dummy variable (PolCon) equal to 1 if the bank is a state-owned banks or a private bank with at least one owner, director, or commissioner (supervisory body) being a political party member, a parliament member, a government official, a former parliament member and/ or a former government official, and zero otherwise. Being politically connected might not only provide banks with more subsidies and profitable contracts from the politicians or the government but also induce them to take higher risk and to operate inefficiently given the firm's protected status.

Following previous studies (Anderson and Reeb, 2004; Berger et al., 2005) we consider bank size (Size) as the natural logarithm of total assets to play an important role as well. Larger banks might benefit from lower average costs due to economies of scales and thus exhibit better performance. Larger banks could also benefit from To-Big-To-Fail (TBTF) safety net subsidies leading to higher risk taking (De Nicolo, 2000). Next, we control for bank diversification (Diver) which is also known to influence risk. Some studies find that diversification into non-traditional banking activities provide benefits such as lower earnings volatility (Boyd et al., 1993), and higher profitability (Elsas et al., 2010). In contrast, other studies find that such diversification strategies reduce bank value (Laeven and Levine, 2007) and risk-adjusted returns because fee-based income tends to be more volatile but not necessarily more profitable than traditional (interest-based) activities (e.g., Berger et al., 2010; DeYoung and Roland, 2001; Stiroh and Rumble, 2006). Hence, we 
include a diversification measure based on the relative importance of net interest income and non-interest income in total income as follows:

$$
\text { Diversification }=1-\left[\left(\frac{\text { Int }}{\text { TOR }}\right)^{2}+\left(\frac{\text { Com }}{\text { TOR }}\right)^{2}+\left(\frac{\text { Trad }}{\text { TOR }}\right)^{2}+\left(\frac{\text { Other }}{\text { TOR }}\right)^{2}\right]
$$

where Int denotes interest income, Com denotes commission revenue, Trad denotes trading revenue, and Other denotes all other revenue. TOR represents total operating revenue and is equal to the sum of Int, Com, Trad, and Other. The use of gross income is believed to better avoid a distorted diversification measure since a loss on some activities will underestimate their importance in bank operations. We also consider bank leverage, measured by equityto-total assets (Capital) ratio, which affects the bank's ability to collect deposits, to lend and hence to earn profits. Banks with high equity ratios are likely to have lower bankruptcy costs and accordingly lower cost of capital that in turn increases their margin or profitability, ceteris paribus.

Banks that are listed on a stock exchange are likely to be exposed to tighter monitoring and market discipline, and therefore their performance and risk should be different from those of non-listed banks. In addition, having a publicly-listed status may allow them to access cheaper sources of funds. Following Liang et al. (2013), we include a dummy variable that equals 1 if the bank is listed (Listed) and 0 otherwise. Similarly, we introduce a dummy variable that takes the value of 1 for a bank with foreign ownership (Foreign) of $50 \%$ or more and 0 otherwise (Claessens and Van Horen, 2014). Such a bank can be a branch of a foreign bank, a subsidiary, or a joint venture entity. While a large number of studies generally conclude that the presence of foreign investors is beneficial in terms of financial stability or loan losses (e.g., Barth et al., 2004; Claessens, 2006; Cull and Martínez Pería, 2013), their presence also leads to lower intermediation cost (i.e. spreads or margins) and lower profitability (Beck et al., 2008; Claessens et al., 2001). We also include the Herfindahl-Hirschman Index (HHI) of banking sector concentration based on banks' assets. It is widely believed that banks' performance and risk vary depending on market concentration. We also consider the deposit insurance regime as a control variable because during the period under study, important changes were brought in terms of maximum coverage particularly from 2005 to 2008. Better covered depositors will likely have a weaker incentive to monitor the bank to prevent it from pursuing riskier activities (Demsetz et al., 1997; Martínez Pería and Schmukler, 2001). Furthermore, explicit deposit insurance 
is often considered as creating higher moral hazard incentives leading to higher financial fragility and increasing the likelihood of bank crises (Demirgüç-Kunt and Detragiache, 2002). Deposit insurance (Covdep) is measured by ln (1+coverage of deposit insurance) where coverage of deposit insurance is the ratio of the explicit coverage limit per deposit account to the average deposit per capita (Angkinand and Wihlborg, 2010; Demirgüç-Kunt, 2005).

\subsection{Regression models}

To test our hypotheses, we consider several models as follows:

$$
\begin{aligned}
& \text { Performance }_{\mathrm{it}}=\alpha_{0}+\beta_{1} \text { Family variable }_{\mathrm{it}}+\sum_{\mathrm{i}, \mathrm{t}=1}^{\mathrm{j}} \beta_{\mathrm{it}} \text { Control variable }_{\mathrm{it}}+\varepsilon_{\mathrm{it}} \text { (1) } \\
& \text { Risk }_{\mathrm{it}}=\alpha_{0}+\beta_{1 \mathrm{t}} \text { Family variable }_{\mathrm{it}}+\sum_{\mathrm{i}, \mathrm{t}=1}^{\mathrm{j}} \beta_{\mathrm{it}} \text { Control variable } \\
& \mathrm{it}
\end{aligned}
$$

Performance is measured by ROA, ROE, adjusted ROA, and adjusted ROE. Risk is measured by ADZP, ADZP1, ADZP2, SDROA, SDROE, and NPL. The Family variable is either Family, Fam_direct, Family_only, or Family_with_inst. Control variable is the vector of other variables as described in Appendix 1.

Pathan (2009) argues that empirical studies on bank governance and performance suffer from endogeneity that partly comes from the nature of the variables. With regard to the estimation model, the independent variables might be influenced by unobserved heterogeneity and might be subject to endogeneity concerns. A specific ownership structure and hence the type of control at a given point in time could be affected by past performance or other characteristics (see, e.g., Bennedsen et al., 2007). Anderson et al. (2011), Hermalin and Weisbach (2003) and Carter et al. (2010) who argue that board structure -e.g., family director- and firm performance are endogenous. For these reasons, we use the instrumental variables (IV) approach in our regressions.

\section{Results}

\subsection{Descriptive Statistics}

We start by reviewing our sample statistics. As aforementioned, this study includes 105 Indonesian banks during the 2001-2008 period consisting of 45 family banks and 60 non- 
family banks. Before we go further, we exclude outliers by eliminating the extreme observations (1\% lowest and 1\% highest values) and check the statistical properties of the considered variables by conducting mean tests and distribution tests for all the variables. Accordingly, we get approximately 840 bank-years observations, of which $42.4 \%$ (356 observations) are for family banks and 57.6\% (484 observations) are for non-family banks. Families can exercise their control through direct ownership or indirectly through affiliated firms. Our sample reveals that almost half of the families (47.5\%) have direct ownership while the rest $(52.5 \%)$ have indirect ownership. Furthermore, 33.9\% (285 observations) of our banks have family members sitting on the board (family directors).

Table 1 presents several descriptive statistics regarding our variables of interest. Nonfamily banks generally exhibit higher performance than family banks in all our measures. On average, the profitability of family banks (ROA and ROE) is two times lower than that of non-family banks. For example, the average ROE for pure family banks, where a family is the only controlling owner, is $11 . \%$ (11.6\% for all family banks irrespective of the presence or not of other institutional shareholders) while for non-family banks it reaches $23 \%$. The differences in the performances of family and non-family banks are statistically significant (see Panel B for mean difference tests). Almost similarly, both the ROA and the ROE are higher in non-family banks than in family banks with institutional ownership (multiple shareholders) but the differences in adjROA and adjROE between both groups are not significant.

\section{[INSERT TABLE 1 HERE ]}

Table 1 also presents our risk measures -i.e. ADZP, ADZP1, and ADZP2, SDROA, SDROA, and NPL- along with other variables considered for the family and non-family banks. Except for ADZP1, family banks exhibit on average lower risk. The mean values of SDROA, SDROE, and NPL are slightly higher for non-family banks than family banks.

Furthermore, 61 of our sample banks have political connections, providing us with 489 bank-years observations (58.2\% of total observations). Around $48 \%$ of family banks and $66.33 \%$ of non-family banks are linked to political power. 
As discussed earlier, family-controlled banks may face constraints to grow because the founders commonly dislike issuing equity and share ownership with outsiders. Therefore such banks might have lower incentives to become larger compared to non-family banks. Table 1 shows that the average size (Size) of non-family banks (Rp18.5 trillion) is approximately three times larger than that of family banks (Rp6.6 trillion). Family banks are also less engaged in more diversified activities (see Diversification in Table 1) and nonfamily banks are more likely to take higher risk and engage in more profitable investment opportunities. The average of the diversification index of non-family banks is equal to $19.9 \%$ while that of family banks is limited to $10.3 \%$. Capital ratios are also, on average, higher in family banks. It is worth to note that, in our sample, a family-controlled bank is more likely to be controlled by a business group. In particular, a larger proportion (86\%) of banks owned by a business group is also family bank. For this reason (i.e., high correlation between family and group dummy which is equal to 0.73 ), we exclude the group dummy in our further analysis.

Table 2 reports the correlation between variables. The presence of a family under its various forms is associated with lower performance as indicated by the negative correlation coefficients.

\section{[INSERT TABLE 2 HERE]}

Turning to risk measures, Table 2 shows a negative correlation between family presence and default risk. Direct ownership (Fam_direct) is related to higher risk but indirect ownership through pyramids is related to lower risk. Family banks with another second largest owner (multiple shareholders) positively correlate with default risk (ADZP and ADZP2) and negatively with income volatility (SDROA and SDROE).

As a whole, family banks generally exhibit lower performance and lower risk than nonfamily banks suggesting that they might prefer to play more safely to secure wealth for their next generation. Nevertheless, direct ownership (Fam_direct) by families is associated with lower performance but also higher risk (except for NPL). 


\subsection{Family ownership, types of control, performance and risk}

As argued above, the explanatory variables used in this study might not be strictly exogenous. Accordingly, it is reasonable to consider that the main variable in our models is an endogenous variable as in previous studies on bank governance (e.g., Anderson and Reeb, 2004; Claessens and Yurtoglu, 2013). Also, under regulatory pressure, distressed banks are often acquired or taken over by non-family investors implying ownership changes.

Previous studies highlight the importance to account for the unobserved effect, and to deal with reverse causality and simultaneity by using an instrumental variables / two-stage least squares approach (IV/2SLS). In our study, we consider regulatory quality and the natural logarithm of the bank's age as the instruments by checking their validity with the Hansen test. Previous studies argue that ownership structure, particularly in emerging markets, is endogenously determined by country circumstances including economic, legal and regulatory infrastructures (Claessens and Fan, 2002; Claessens and Yurtoglu, 2013; Shleifer and Vishny, 1997). For this purpose, we use the regulatory quality / rule of law index ${ }^{4}$, a part of The Worldwide Governance Indicator developed by Kaufmann et al. (2010). This indicator captures the perceptions of the ability of the country to formulate and implement sound policies and regulations that permit and promote private sector development. The age (in natural logarithm) of the bank, by construction, is exogenous and is often used as an instrument in the literature (Wintoki et al., 2012).

Table 3 reports the regression results using the IV approach. For each model, we indicate the estimated coefficients, t-statistics, Hansen tests of instrument validity, F-test and the number of observations. Except for model (3) Panel B, none of the Hansen tests present any statistical significance. This indicates that the null hypothesis that all instruments are uncorrelated with the error term is not rejected and therefore our instruments in all models are valid. Our results suggest that F-statistics across all $1^{\text {st }}$ stage regressions in our models are greater than the cut-off value of 10 (Staiger and Stock, 1997; Stock et al., 2002) ${ }^{5}$, which suggests that our instrument is relevant and does not suffer from weak instrument concerns. Further, family variables are empirically endogenous and affected by variables including the instruments as reported by endogeneity test results (last row of Table 3).

\footnotetext{
${ }^{4}$ During the period covered by our sample, Indonesia experienced several political and regulatory changes which substantially impacted banking regulation.

${ }^{5}$ To conserve space, the outputs are not reported here but available from authors upon request.
} 


\section{[INSERT TABLE 3 HERE]}

Panel A presents the regression results with ROA, ROE, adjusted ROA and adjusted ROE as the dependent variables. The coefficients of Family show negative signs, indicating that the presence of families leads to lower performance. This evidence is consistent with Filatotchev et al. (2005), Morck et al. (1988) and Barry et al. (2011).

As mentioned above, we introduce several types of family control namely direct ownership (Fam_direct), Family_only, and Family_with_inst. For the first category, Fam_direct, in which the family has substantial direct ownership (10\% threshold) the results are quite similar to those in Panel A; direct control by a family (Fam_direct) has a negative impact on ROA, ROE, adjROA, and adjROE (see Panel B, Table 3). This suggests that direct control by family is not only related to lower performance as measured by ROA and ROE, but also to lower risk-adjusted returns (adjROA and adjROE). This result is presumably driven by a reduction in performance rather than an increase in risk as suggested by the correlation matrix.

Panel C reports the results when we use Family_only as our main variable. We find that the coefficients of Family_only are all negative and significant for all our performance measures (ROA, ROE, adjROA and adjROE). The results above support the argument that family direct ownership negatively affects performance. Family banks probably face several problems such as domination of their interest over those of non-family shareholders, inappropriate board structure and assignment, or other expropriation behavior leading to lower performance (Anderson et al., 2009; DeAngelo and DeAngelo, 2000). In Panel D, we consider the presence of an institutional shareholder holding a significant equity stake as the second largest investor ${ }^{6}$. We conjecture that such an owner can effectively challenge the powerful controlling family. Our results show a positive impact of Family_with_inst (multiple shareholders) on performance, suggesting that such an ownership structure allows monitoring and discipline to operate effectively. The presence of an institutional shareholder

\footnotetext{
${ }^{6}$ One can argue that institutional investors are only attracted by particular family banks. Hence, we run a causality test and find that institutional investors are not affected by family, or vice versa. However, regulations such as on merger, acquisition, and recapitalization following the 1998 financial crisis as captured by our instruments can influence the presence of institutional investors as the second largest owner.
} 
as the second largest shareholder positively influences performance as argued in previous studies (Attig et al., 2008; Claessens and Yurtoglu, 2013; Laeven and Levine, 2008).

Political connections, particularly to the ruling parties, not only provide favorable deals and protected status (Adams et al., 2010; Goldman et al., 2009; Johnson and Mitton, 2003) but are also likely to expose the bank's performance to adverse political changes (Fisman, 2001; Gul, 2006). Our results show that this variable is related to lower performance, but its impact becomes positive (Panel D).

We find that being a listed bank (Listed) does not significantly impact performance. Next, supposedly, larger banks are able to achieve better performance but our results show that size negatively affects ROA and ROE in Panel A and C. Higher capital ratios are found to positively affect profitability.

Our results also show that diversification is negatively associated with adjROA and adjROE but not significantly linked with ROA and ROA, suggesting the presence of a positive effect on risk. Further, the impact on performance of Foreign is negative in line with Claessens et al. (2001) and Beck et al. (2008). Lastly, our results indicate that market concentration (HHI), which was driven down by regulation during our sample period, positively affects performance.

Regarding risk taking behavior, as discussed earlier, family ownership could prevent the bank from taking optimal investments if the family believes that by doing so the bank will bear more risk and in turn might not ensure wealth and business continuation for the next generation. Consequently, the expected impact of Family on risk should be negative. However, since information distortion is arguably prevalent in family-controlled banks, it is difficult for outside investors to estimate the business risk profiles. Also, the family might have strong incentives to distort information in order to extract private benefits (Anderson et al., 2009). The bank might find it reasonable to take higher risk since, for any level of risk it takes, outside investors will charge the above average rate of return because of asymmetric information. This problem is more pronounced in emerging markets, given that investor protection is commonly poor. The family has a higher incentive to expropriate and also to take higher risk at the expense of minority shareholders, particularly in the absence of another blockholder (Claessens and Fan, 2002; Claessens and Yurtoglu, 2013). Considering the two arguments above, the net effect probably depends on which argument is more 
dominant. For this purpose, we run regressions of risk measures (ADZP, ADZP1, ADZP2, SDROA, SDROE, and NPL) on family variables and report the results in Table 4.

\section{[ INSERT TABLE 4 HERE ]}

Panel A (Table 4) presents the regressions with Family as the main variable. Our results show that the coefficients of Family, irrespective of ownership structure, are associated with higher risk. More specifically, Family is associated with higher default risk (ADZP, AZDP1, and ADZP2) and higher income volatility (SDROA and SDROE). The coefficient for NPL, however, is not significant. In Panels B, where the variable of interest is respectively Fam_direct all the coefficients are significant and indicate a positive effect on risk. The same findings hold for Panel $\mathrm{C}$ where the variable of interest is Family only i.e. banks with a family as the only controlling owner. Hence, the risk taking incentives proposition appears to dominate the risk aversion proposition yielding higher risk in family banks. In contrast, when we use Family_with_inst, bank risk decreases as shown by the positive and significant coefficients for default risk and negative and significant for income volatility and loan risk. Again, our findings hence support the importance of the role played by the second largest shareholder in an emerging market (Claessens et al., 2002; Claessens and Yurtoglu, 2013; Shleifer and Vishny, 1997).

Moving to control variables, the political connection variable systematically exhibits a significant positive sign highlighting the positive impact of such connections on risk. Regarding the other control variables, no conclusive results can be drawn for Listed and Size but capitalization is positively associated with income volatility (SDROA) and loan risk (NPL) indicating that better capitalized banks take more risk. Consistent with previous studies (e.g., Berger et al., 2010; DeYoung and Roland, 2001; Stiroh and Rumble, 2006), diversification is positively associated with default risk, income volatility, and loan risk. Foreign banks do not systematically exhibit different risk profiles with our various indicators and a higher market concentration (HHI) significantly increases risk as shown by the negative signs for ADZP, ADZP1, and ADZP2 and positive signs for SDROA, SDROE, and NPL. Lastly, the coefficient of the deposit insurance variable (Covdep), negative for ADZP, 
ADZP1, and ADZP2, and positive for SDROA, SDROE, and NPL, indicates that the presence of such a scheme encourages banks to take more risk.

\subsection{The impact of family directors}

As discussed above, more than half of East Asian firms are controlled by families and Claessens et al. (2000) find that the separation of management from ownership control is rare and that two firms out of three have family-related directors. Previous studies also highlight that the involvement of family members has a significant impact on the firm's policy and performance (see, e.g., Anderson et al., 2009; Bennedsen et al., 2007; Pérez-González, 2006; Villalonga and Amit, 2006). Anderson and Reeb (2003) and Anderson et al. (2012) argue that family directors, a proxy for active family control, can more readily align the firm's interests with those of the family, suggesting that their impact is potentially magnified.

The appointment of outside-family directors (professional directors) will lead to the misalignment of their interests. Nevertheless, some suggest that a family tends to appoint its members on the board although they are less efficient or less capable than professional managers available on the market (Morck et al., 2005; Pérez-González, 2006). The family director potentially feels less accountable than outside directors because the family is mostly biased to its member, suggesting that tenure, talent and other top management criteria are no longer necessary. Bertrand et al. (2008) find that greater involvement by family members is associated with lower performance due to the dilution of ownership and control across equally powerful descendants. Hence, to investigate the governance effect of such an involvement we introduce a dummy variable, Family director, which takes the value of 1 if the family has its member(s) sitting on the board. This allows us to examine to what extent the presence of such directors has an influence on performance.

\section{[ INSERT TABLE 5 HERE ]}

Table 5 reports our results with the family director dummy as the variable of interest. The presence of family members on the board is related to lower performance, including riskadjusted returns (adjROA \& adjROE), supporting Villalonga and Amit (2006). Anderson et al. (2003) interpret this result as the effect of obtaining directorship position through family ties rather than job qualification. Family's active involvement through its family director 
induces the bank to take higher default risk, income volatility, and loan risk (see Panel B). These results support the argument that families can easily extract benefits and expropriate other minority shareholders (Bertrand et al., 2008; Shleifer and Vishny, 1997).

Again, as argued above, the adverse effect of family director's appointment could be mitigated by the presence of an institutional investor with substantial stakes in the bank. Table 6 reports that the coexistence of family directors and an institutional investor holding at least $10 \%$ of the bank's shares, captured by the dummy variable Family director_with_inst, is beneficial for the bank as shown by its positive impact on performance. Furthermore, the presence of an institutional investor is associated with lower default risk, income volatility, and loan risk. Such findings are in line with Miller and Le Breton-Miller (2006) who argue that outside monitoring of family director-led banks is beneficial to limit discretionary actions and excessive risk taking.

\section{[ INSERT TABLE 6 HERE ]}

\subsection{Other specification and robustness check}

In the previous section we have used Fam_direct to examine the impact of direct ownership on performance and risk. To check the robustness of our results, we here consider indirect control (Fam_indirect) that equals one if the family owns the bank through ultimate shareholding (pyramidal structure) with a minimum of $10 \%$ control along the ownership chain. We find similar results which are reported in Table 6. Indirect control through pyramids is associated with better performance and lower risk.

\section{[ INSERT TABLE 7 HERE ]}

Second, we further examine whether our results still hold when we impose a threshold of $25 \%$ which is used by the Indonesian regulatory authorities to define the controlling owners. We find similar results with regard to the effect of family ownership on performance and risk $^{7}$. Because of data limitation on multiple shareholders (i.e., family ownership combined with another institutional investor at the $25 \%$ threshold), our sample size does not allow estimating accurate results for the presence institutional investors in family banks.

\footnotetext{
${ }^{7}$ For brevity, we do not report all the figures. They are available from the authors upon request.
} 
We also run regressions by excluding Foreign which is presumably strongly and negatively correlated with Family. Indeed, family banks are less likely to open their doors to foreigners. Our results are unaltered. Also, larger banks have more opportunities to diversify their activities and there is hence possible collinearity between size and diversification. We therefore exclude Diversification from our models. Again, our main results remain unchanged.

\section{Conclusion}

Our study investigates the effect of family control on bank performance and risk. We consider the case of Indonesia where almost half of the banks are owned by families. Such families often own the bank directly and usually appoint their members on the board. But they sometimes also control the bank through affiliated firms. In all cases, our results highlight that family ownership significantly affects bank performance and risk.

Specifically, our findings show that, under its various forms (direct ownership, pure family ownership, family directors), family ownership negatively affects performance. Furthermore, when a family is the single controlling owner or appoints its directors on the board, we find that its impact is persistently negative. In contrast, the presence of an institutional investor as the second largest owner in a family bank is related to better performance. Our results also show that family ownership, under its various forms, is associated with higher risk taking and default risk. But again, we find the opposite result when institutional investors are strongly present as second largest owners. Our findings are generally robust to alternative model specifications and sets of control variables.

Our results have important policy implications for emerging markets and Indonesia more specifically. The existing regulations on corporate governance that, for instance, only require banks to declare familial relationships (i.e., between a director and other directors, commissioner, and controlling shareholders), and to have a familial-independent president director, cannot prevent banks from taking higher risk and performing more poorly. The controlling family can assign its members as the family directors (as long as he/she is not the president director), to exert a more active involvement in the bank, and possibly to emphasize the family's interests. Inadequate regulations can easily entice the family bank to focus on business succession for the next generation although doing so means taking less-profitable 
and suboptimal investments. The presence of multiple shareholders (i.e., family combined with institutional ownership) is a possible solution to effectively improve bank performance and reduce risk taking. 


\section{REFERENCES}

Adams, R.B., Hermalin, B.E., Weisbach, M.S., 2010. The role of boards of directors in corporate governance: A conceptual framework and survey. Journal of Economic Literature 48, 58-107.

Agrawal, A., Knoeber, C., 2001. Do some outside directors play a political role? Journal of Law and Economics 44, 179-198.

Anderson, R.C., Duru, A., Reeb, D.M., 2009. Founders, heirs, and corporate opacity in the United States. Journal of Financial Economics 92, 205-222.

Anderson, R.C., Duru, A., Reeb, D.M., 2012. Investment policy in family controlled firms. Journal of Banking \& Finance 36, 1744-1758.

Anderson, R.C., Mansi, S.A., Reeb, D.M., 2003. Founding family ownership and the agency cost of debt. Journal of Financial Economics 68, 263-285.

Anderson, R.C., Reeb, D.M., 2003. Founding-family ownership and firm performance: Evidence from the S\&P 500. Journal of Finance 58, 1301-1328.

Anderson, R.C., Reeb, D.M., 2004. Board composition: Balancing family in S\&P 500 firms. Administrative Science Quarterly 49, 209-237.

Anderson, R.C., Reeb, D.M., Upadhyay, A., Zhao, W., 2011. The economics of director heterogeneity. Financial Management 40, 5-38.

Angkinand, A., Wihlborg, C., 2010. Deposit insurance coverage, ownership, and banks' risktaking in emerging markets. Journal of International Money and Finance 29, 252-274.

Arregle, J., Hitt, M.A., Sirmon, D.G., Very, P., 2007. The development of organizational social capital: Attributes of family firms. Journal of Management Studies 44, 73-95.

Asian Development Bank, 2000. Corporate Governance and Finance in East Asia: A consolidated report. Asian Development Bank (ADB), Manila, Philippines.

Attig, N., Guedhami, O., Mishra, D., 2008. Multiple large shareholders, control contests, and implied cost of equity. Journal of Corporate Finance 14, 721-737.

Bammens, Y., Voordeckers, W., Van Gils, A., 2011. Boards of Directors in Family Businesses: A Literature Review and Research Agenda. International Journal of Management Reviews 13, 134-152.

Bank for International Settlements (BIS), 2010. Principles for enhancing bank corporate governance - consultative document. Bank for International Settlements. 
Bank Indonesia (BI), 2006a. Peraturan Bank Indonesia tentang kepemilikan tunggal pada perbankan Indonesia, 8/16/PBI/2006 Jakarta, Indonesia.

Bank Indonesia (BI), 2006b. Peraturan Bank Indonesia tentang pelaksanaan good corporate governance bagi bank umum, 8/4/PBI/2006, Jakarta, Indonesia.

Bank Indonesia (BI), 2006c. Peraturan Bank Indonesia tentang perubahan atas PBI No. 8/4/PBI/2006 tentang pelaksanaan good corporate governance pada bank umum, 8/14/PBI/2006, Jakarta, Indonesia.

Bank Indonesia (BI), 2007. Surat Edaran BI perihal pelaksanaan good corporate governance bagi bank umum, 9/12/DPNP, Jakarta, Indonesia.

Barney, J.B., 2001. Resource-based theories of competitive advantage: A ten-year retrospective on the resource-based view. Journal of Management 27, 643-650.

Barry, T.A., Lepetit, L., Tarazi, A., 2011. Ownership structure and risk in publicly held and privately owned banks. Journal of Banking \& Finance 35, 1327-1340.

Barth, J.R., Caprio Jr, G., Levine, R., 2004. Bank regulation and supervision: what works best? Journal of Financial Intermediation 13, 205-248.

Beck, T., Demirguc-Kunt, A., Laeven, L., Levine, R., 2008. Finance, Firm Size, and Growth. Journal of Money, Credit and Banking 40, 1379-1405.

Bennedsen, M., Nielsen, K.M., Perez-Gonzalez, F., Wolfenzon, D., 2007. Inside the family firm: The role of families in succession decisions and performance. The Quarterly Journal of Economics 122, 647-691.

Berger, A.N., Clarke, G.R.G., Cull, R., Klapper, L., Udell, G.F., 2005. Corporate governance and bank performance: A joint analysis of the static, selection, and dynamic effects of domestic, foreign, and state ownership. Journal of Banking \& Finance 29, 2179-2221.

Berger, A.N., Hasan, I., Zhou, M., 2010. The effects of focus versus diversification on bank performance: Evidence from Chinese banks. Journal of Banking \& Finance 34, 1417-1435.

Bertrand, M., Johnson, S., Samphantharak, K., Schoar, A., 2008. Mixing family with business: A study of Thai business groups and the families behind them. Journal of Financial Economics 88, 466-498.

Bertrand, M., Schoar, A., 2006. The role of family in family firms. Journal of Economic Perspectives 20, 73-96. 
Boubakri, N., Guedhami, O., Mishra, D., 2010. Family control and the implied cost of equity: Evidence before and after the Asian financial crisis. Journal of International Business Studies 41, 451-474.

Boyd, J.H., Graham, S.L., Hewitt, R.S., 1993. Bank holding company mergers with nonbank financial firms: Effects on the risk of failure. Journal of Banking \& Finance 17, 43-63.

Brown, C.O., Dinç, I.S., 2005. The politics of bank failures: Evidence from emerging markets. The Quarterly Journal of Economics 120, 1413-1444.

Bunkanwanicha, P., Gupta, J., Wiwattanakantang, Y., 2012. Banks in family business groups: Pyramid, lending behaviour, and financial crisis. Working paper.

Carretta, A., Farina, V., Gon, A., Parisi, A., 2012. Politicians 'on board': Do political connections affect banking activities in Italy? European Management Review 9, 75-83.

Carter, D.A., D'Souza, F., Simkins, B.J., Simpson, W.G., 2010. The Gender and Ethnic Diversity of US Boards and Board Committees and Firm Financial Performance. Corporate Governance: An International Review 18, 396-414.

Casson, M., 1999. The economics of the family firm. Scandinavian Economic History Review $47,10-23$.

Chakrabarty, S., 2009. The influence of national culture and institutional voids on family ownership of large firms: A country level empirical study. Journal of International Management $15,32-45$.

Chandler, A.D., Jr., 1990. Scale and scope: The dynamics of industrial capitalism. Harvard University Press, Cambridge, MA,.

Chin, C.L., Kleinman, G., Lee, P., Lin, M.F., 2006. Corporate ownership structure and accuracy and bias of mandatory earnings forecast: Evidence from Taiwan. Journal of International Accounting Research 5, 41-62.

Chu, W., 2009. Family ownership and firm performance: Influence of family management, family control, and firm size. Asia Pacific Journal of Management 28, 833-851.

Chung, H.-M., Chan, S.-T., 2012. Ownership structure, family leadership, and performance of affiliate firms in large family business groups. Asia Pacific Journal of Management 29, 303-329.

Claessens, S., 2006. Competitive implications of cross-border banking, in: Caprio, G., Evanoff, D.D., Kaufman, G.G. (Eds.), Cross-border banking: Regulatory challenges World Scientific Pub Co Inc, p. 492. 
Claessens, S., Demirgüç-Kunt, A., Huizinga, H., 2001. How does foreign entry affect domestic banking markets? Journal of Banking \& Finance 25, 891-911.

Claessens, S., Djankov, S., Lang, L.H.P., 2000. The separation of ownership and control in East Asian Corporations. Journal of Financial Economics 58, 81-112.

Claessens, S., Fan, J.P.H., 2002. Corporate governance in Asia: A survey. International Review of Finance 3, 71-103.

Claessens, S., Feijen, E., Laeven, L., 2008. Political connections and preferential access to finance: The role of campaign contributions. Journal of Financial Economics 88, 554-580.

Claessens, S., Simeon, D., Fan, J.P.H., Lang, L.H.P., 2002. Disentangling the incentive and entrenchment effects of large shareholdings. The Journal of Finance 57, 2741-2771.

Claessens, S., Van Horen, N., 2014. Foreign Banks: Trends and Impact. Journal of Money, Credit and Banking 46, 295-326.

Claessens, S., Yurtoglu, B.B., 2013. Corporate governance in emerging markets: A survey. Emerging Markets Review 15, 1-33.

Cruz, C.C., Gómez-Mejia, L.R., Becerra, M., 2010. Perceptions of benevolence and the design of agency contracts: CEO-TMT relationships in family firms. Academy of Management Journal 53, 69-89.

Cull, R., Martínez Pería, M.S., 2013. Chapter 14 - Foreign bank participation in developing countries, in: Caprio, G., Beck, T., Claessens, S., Schmukler, S.L. (Eds.), The Evidence and Impact of Financial Globalization. Academic Press, San Diego, pp. 213-222.

Davis, J.H., Schoorman, F.D., Donaldson, L., 1997. Toward a stewardship theory of management Academy of Management Review 22, 20-47.

De Nicolo, G., 2000. Size, charter value and risk in banking: an international perspective. International Finance Discussion Papers.

DeAngelo, H., DeAngelo, L., 2000. Controlling stockholders and the disciplinary role of corporate payout policy: a study of the Times Mirror Company. Journal of Financial Economics 56, 153-207.

Demirgüç-Kunt, A., 2005. Deposit insurance around the world: A comprehensive database. Washington, DC : World Bank, Development Research Group, Finance Team.

Demirgüç-Kunt, A., Detragiache, E., 2002. Does deposit insurance increase banking system stability? An empirical investigation. Journal of Monetary Economics 49, 1373-1406. 
Demsetz, H., Lehn, K., 1985. The Structure of Corporate Ownership: Causes and Consequences. Journal of Political Economy 93, 1155-1177.

Demsetz, R.S., Saidenberg, M.R., Strahan, P.E., 1997. Agency problems and risk taking at banks. Federal Reserve Bank of New York Staff Reports 9709.

DeYoung, R., Roland, K.P., 2001. Product mix and earnings volatility at commercial banks: Evidence from a degree of total leverage model. Journal of Financial Intermediation 10, 54-84.

Elsas, R., Hackethal, A., Holzhäuser, M., 2010. The anatomy of bank diversification. Journal of Banking \& Finance 34, 1274-1287.

Faccio, M., Lang, L.H.P., 2002. The ultimate ownership of Western European corporations. Journal of Financial Economics 65, 365-395.

Fama, E.F., Jensen, M.C., 1983. Separation of ownership and control. Journal of Law and Economics 26, 301-325.

Fan, J.P.H., Wong, T.J., 2002. Corporate ownership structure and the informativeness of accounting earnings in East Asia. Journal of Accounting and Economics 33, 401-425.

Filatotchev, I., Lien, Y.-C., Piesse, J., 2005. Corporate governance and performance in publicly listed, family-controlled firms: Evidence from Taiwan. Asia Pacific Journal of Management 22, 257-283.

Fisman, R., 2001. Estimating the Value of Political Connections. American Economic Review 91, 1095-1102.

Francis, B.B., Hasan, I., Sun, X., 2009. Political connections and the process of going public: Evidence from China. Journal of International Money and Finance 28, 696-719.

Giovannini, R., 2009. Corporate governance, family ownership and performance. Journal of Management \& Governance 14, 145-166.

Goldman, E., Rocholl, J., So, J., 2009. Do politically connected boards affect firm value? Review of Financial Studies 22, 2331-2360.

Gomez-Mejia, L.R., Nuñez-Nickel, M., Gutierrez, I., 2001. The role of family ties in agency contracts. The Academy of Management Journal 44, 81-95.

Government Indonesia (GoI), 1999. Peraturan Pemerintah No. 28 Tahun 1999 tentang Merger, Konsolidasi dan Akuisisi Bank, Jakarta, Indonesia.

Government of Indonesia (GoI), 2004. Undang-undang No. 3/2004 tantang perubahan atas undang-undang Republik Indonesia No. 23/1999 tentang Bank Indonesia, Jakarta, Indonesia. 
Goyeau, D., Tarazi, A., 1992. Evaluation of risk of failure banking in Europe. Journal of Political Economy 102, 249-280.

Gul, F.A., 2006. Auditors' response to political connections and cronyism in Malaysia. Journal of Accounting Research 44, 931-963.

Habbershon, T.G., Williams, M.L., 1999. A resource-based framework for assessing the strategic advantage of family firms. Family Business Review 12, 1-25.

Hanazaki, M., Liu, Q., 2007. Corporate governance and investment in East Asian firmsempirical analysis of family-controlled firms. Journal of Asian Economics 18, 76-97.

Hermalin, B.E., Weisbach, M.S., 2003. Boards of directors as an endogenously determined institution: A survey of the economic literature. Economic Policy Review, Federal Reserve Bank of New York, 7-26.

Heugens, P.M.A.R., van Essen, M., van Oosterhout, J., 2009. Meta-analyzing ownership concentration and firm performance in Asia: Towards a more fine-grained understanding. Asia Pacific Journal of Management 26, 481-512.

Hoopes, D.G., Miller, D., 2006. Ownership preferences, competitive heterogeneity, and familycontrolled businesses. Family Business Review 19, 89-101.

James, H.S., 1999. Owner as manager, extended horizons and the family firm. International Journal of the Economics of Business 6, 41-45.

Jensen, M.C., Meckling, W.H., 1976. Theory of the firm: Managerial behavior, agency costs and ownership structure. Journal of Financial Economics 3, 305-360.

Jiang, Y., Peng, M., 2011a. Principal-principal conflicts during crisis. Asia Pacific Journal of Management 28, 683-695.

Jiang, Y., Peng, M.W., 2011b. Are family ownership and control in large firms good, bad, or irrelevant? Asia Pacific Journal of Management 28, 15-39.

Joh, S.W., 2003. Corporate governance and firm profitability: evidence from Korea before the economic crisis. Journal of Financial Economics 68, 287-322.

Johnson, S., Mitton, T., 2003. Cronyism and capital controls: evidence from Malaysia. Journal of Financial Economics 67, 351-382.

Kaufmann, D., Kraay, A., Mastruzzi, M., 2010. The Worldwide Governance Indicator: A summary of methodology, data, ad analytical issues. World Bank Policy Research Working Paper 5430. 
La Porta, R., Lopez-de-Silanes, F., Shleifer, A., 1999. Corporate ownership around the world. The Journal of Finance 54, 471-517.

Laeven, L., Levine, R., 2007. Is there a diversification discount in financial conglomerates? Journal of Financial Economics 85, 331-367.

Laeven, L., Levine, R., 2008. Complex ownership structures and corporate valuations. Review of Financial Studies 21, 579-604.

Lang, M.H., Lins, K.V., Miller, D.P., 2004. Concentrated control, analyst following, and valuation: Do analysts matter most when investors are protected least? Journal of Accounting Research 42, 589-623.

Lee, K., Peng, M.W., Lee, K., 2008. From diversification premium to diversification discount during institutional transitions. Journal of World Business 43, 47-65.

Lehmann, E., Weigand, J., 2000. Does the governed corporation perform better? Governance structures and corporate performance in Germany. European Finance Review 4, 157-195.

Lepetit, L., Nys, E., Rous, P., Tarazi, A., 2008. Bank income structure and risk: An empirical analysis of European banks. Journal of Banking \& Finance 32, 1452-1467.

Liang, Q., Xu, P., Jiraporn, P., 2013. Board characteristics and Chinese bank performance. Journal of Banking \& Finance 37, 2953-2968.

Lin, S.L., Wu, M.F., 2010. Family ownership and risk taking: Exploring nonlinear effects in the financial industry. African Journal of Business Management 4, 3738-3751.

Lindsey, T., 2008. Indonesia: Law and Society, 2nd Revised ed. Irwin Law, Sydney, NSW.

Liu, H., Molyneux, P., Nguyen, L.H., 2011. Competition and risk in South East Asian commercial banking. Applied Economics 44, 3627-3644.

Liu, W., Yang, H., Zhang, G., 2012. Does family business excel in firm performance? An institution-based view. Asia Pacific Journal of Management 29, 965-987.

Luo, X., Chung, C.-N., 2005. Keeping it all in the family: The role of particularistic relationships in business group performance during institutional transition. Administrative Science Quarterly 50, 404-439.

Martínez, J.I., Stöhr, B.S., Quiroga, B.F., 2007. Family ownership and firm performance: Evidence from public companies in Chile. Family Business Review 20, 83-94.

Martínez Pería, M.S., Schmukler, S.L., 2001. Do depositors punish banks for bad behavior? Market discipline, deposit insurance, and banking crises. The Journal of Finance 56, 1029-1051. 
Maury, B., 2006. Family ownership and firm performance: Empirical evidence from Western European corporations. Journal of Corporate Finance 12, 321-341.

Miller, D., Le Breton-Miller, I., 2006. Family governance and firm performance: Agency, stewardship, and capabilities. Family Business Review 19, 73-87.

Miller, D., Le Breton-Miller, I., Lester, R.H., 2011. Family and Lone Founder Ownership and Strategic Behaviour: Social Context, Identity, and Institutional Logics. Journal of Management Studies 48, 1-25.

Morck, R., Shleifer, A., Vishny, R.W., 1988. Management ownership and market valuation: An empirical analysis. Journal of Financial Economics 20, 293-315.

Morck, R., Wolfenzon, D., Yeung, B., 2005. Corporate governance, economic entrenchment, and growth. Journal of Economic Literature 43, 655-720.

Morck, R., Yeung, B., 2003. Agency problems in large family business groups. Entrepreneurship Theory and Practice 27, 367-382.

Naldi, L., Nordqvist, M., Sjöberg, K., Wiklund, J., 2007. Entrepreneurial orientation, risk taking, and performance in family firms. Family Business Review 20, 33-47.

Nys, E., Tarazi, A., Trinugroho, I., 2014. Political connections, bank deposits, and formal deposit insurance. Working Paper. Available at http://ssrn.com/abstract=2070547.

Obata, S., 2003. Pyramid business groups in East Asia: Insurance or tunneling? CEI Working Paper Series 2002-13.

Pathan, S., 2009. Strong boards, CEO power and bank risk-taking. Journal of Banking \& Finance 33, 1340-1350.

Peng, M.W., Jiang, Y., 2010. Institutions behind family ownership and control in large firms. Journal of Management Studies 47, 253-273.

Pérez-González, F., 2006. Inherited control and firm performance. American Economic Review 96, 1559-1588.

Pindado, J., Requejo, I., 2014. Family business performance from a governance perspective: A review of empirical research. International Journal of Management Reviews, n/a-n/a.

Pindado, J., Requejo, I., de la Torre, C., 2014. Family control, expropriation, and investor protection: A panel data analysis of Western European corporations. Journal of Empirical Finance 27, 58-74. 
Sacristán-Navarro, M., Gómez-Ansón, S., Cabeza-García, L., 2011. Large shareholders' combinations in family firms: Prevalence and performance effects. Journal of Family Business Strategy 2, 101-112.

Schulze, W.S., Lubatkin, M.H., Dino, R.N., 2003. Toward a theory of agency and altruism in family firms. Journal of Business Venturing 18, 473-490.

Shleifer, A., Vishny, R.W., 1997. A Survey of Corporate Governance. Journal of Finance 52, 737-783.

Staiger, D., Stock, J.H., 1997. Instrumental variables regression with weak instruments. Econometrica 65, 557-586.

Stiroh, K.J., Rumble, A., 2006. The dark side of diversification: The case of US financial holding companies. Journal of Banking \& Finance 30, 2131-2161.

Stock, J.H., Wright, J.H., Yogo, M., 2002. A survey of weak instruments and weak identification in Generalized Method of Moments. Journal of Business \& Economic Statistics 20, 518-529.

Villalonga, B., Amit, R., 2006. How do family ownership, control and management affect firm value? Journal of Financial Economics 80, 385-417.

Wintoki, M.B., Linck, J.S., Netter, J.M., 2012. Endogeneity and the dynamics of internal corporate governance. Journal of Financial Economics 105, 581-606.

Wright, M., Kellermanns, F.W., 2011. Family firms: A research agenda and publication guide. Journal of Family Business Strategy 2, 187-198.

Wu, Z., Chua, J.H., Chrisman, J.J., 2007. Effects of family ownership and management on small business equity financing. Journal of Business Venturing 22, 875-895.

Xie, B., Davidson Iii, W.N., DaDalt, P.J., 2003. Earnings management and corporate governance: the role of the board and the audit committee. Journal of Corporate Finance 9, 295316.

Zhuang, J., David, E., Webb, D.C., Capulong, M.V., 2000. Corporate governance and finance in East Asia: a study of Indonesia, Republic of Korea, Malaysia, Philippines, and Thailand. Asian Development Bank, Manila, Philippines. 
Table 1. Descriptive Statistics of family bank performance and risk

Panel A. Descriptive for family and non family baks

\begin{tabular}{|c|c|c|c|c|c|c|c|c|c|c|c|c|c|c|c|c|}
\hline & ROA & ROE & adjROA & adjROE & ADZP & ADZP1 & ADZP2 & SDROA & SDROE & NPL & Asset & Diver & Capital & Foreign & PolCon & d_group \\
\hline \multicolumn{17}{|c|}{ Non-family banks } \\
\hline Mean & 3.263 & 22.628 & 5.311 & 5.405 & 34.713 & 6.517 & 27.182 & 1.426 & 11.255 & 5.530 & 18500 & 19.896 & 11.502 & 0.3471 & 0.6570 & 0.1240 \\
\hline SD & 1.988 & 14.446 & 4.941 & 6.975 & 103.505 & 6.554 & 80.861 & 2.852 & 17.521 & 7.689 & 44000 & 15.924 & 7.548 & 0.4765 & 0.4752 & 0.3299 \\
\hline Min & -6.940 & -27.890 & -1.798 & -1.314 & 0.536 & 0.124 & 0.140 & 0.012 & 0.059 & 0.000 & 89.8 & 1.010 & 0.260 & 0 & 0 & 0 \\
\hline Median & 3.245 & 21.360 & 3.907 & 3.085 & 22.133 & 4.744 & 17.038 & 0.797 & 6.080 & 3.265 & 4128.715 & 13.746 & 9.663 & 0 & 1 & 0 \\
\hline $\operatorname{Max}$ & 10.410 & 69.930 & 27.608 & 58.962 & 1848.302 & 56.024 & 1449.642 & 49.195 & 154.676 & 47.390 & 338000 & 65.250 & 52.942 & 1 & 1 & 1 \\
\hline $\mathrm{N}$ & 482 & 475 & 473 & 470 & 361 & 351 & 355 & 480 & 471 & 480 & 484 & 481 & 470 & 484 & 484 & 484 \\
\hline \multicolumn{17}{|c|}{ Pure family banks } \\
\hline Mean & 1.695 & 11.050 & 4.115 & 3.811 & 47.016 & 5.131 & 42.436 & 1.415 & 9.764 & 3.523 & 5587 & 8.870 & 14.987 & 0 & 0.497 & 0.844 \\
\hline SD & 2.696 & 11.394 & 5.207 & 5.489 & 71.549 & 5.672 & 68.679 & 2.061 & 19.137 & 3.822 & 26200 & 5.693 & 10.056 & 0 & 0.501 & 0.363 \\
\hline Min & -10.660 & -36.020 & -1.836 & -1.622 & 0.070 & 0.008 & 0.665 & 0.031 & 0.079 & 0.000 & 11.76 & 0.336 & 3.141 & 0 & 0 & 0 \\
\hline Median & 1.570 & 9.840 & 2.691 & 2.434 & 26.647 & 3.069 & 22.339 & 0.685 & 4.273 & 2.455 & 454.291 & 7.544 & 11.779 & 0 & 0 & 1 \\
\hline Max & 15.210 & 56.380 & 31.283 & 51.845 & 641.869 & 32.143 & 625.939 & 17.121 & 191.933 & 23.170 & 245000 & 32.095 & 50.145 & 0 & 1 & 1 \\
\hline $\mathrm{N}$ & 308 & 299 & 300 & 299 & 227 & 207 & 227 & 308 & 307 & 304 & 308 & 302 & 300 & 308 & 308 & 308 \\
\hline \multicolumn{17}{|c|}{ Family \& institutional banks } \\
\hline Mean & 2.484 & 15.210 & 5.241 & 4.193 & 40.321 & 5.299 & 35.173 & 0.920 & 7.469 & 5.285 & 13300 & 19.870 & 17.107 & 0.167 & 0.396 & 0.938 \\
\hline SD & 2.544 & 15.443 & 4.861 & 4.635 & 38.076 & 5.061 & 33.844 & 0.813 & 8.595 & 4.508 & 16300 & 11.421 & 10.498 & 0.377 & 0.494 & 0.245 \\
\hline Min & -7.430 & -19.450 & -0.838 & -1.015 & 2.853 & 0.316 & 3.612 & 0.050 & 0.145 & 0.430 & 218.15 & 3.133 & 6.722 & 0 & 0 & 0 \\
\hline Median & 2.220 & 13.325 & 3.635 & 2.781 & 26.526 & 3.547 & 23.204 & 0.557 & 4.027 & 3.630 & 4519.093 & 17.960 & 14.649 & 0 & 0 & 1 \\
\hline Max & 8.510 & 64.510 & 25.400 & 22.172 & 189.492 & 26.400 & 163.092 & 3.657 & 40.236 & 21.970 & 62800 & 41.958 & 51.069 & 1 & 1 & 1 \\
\hline $\mathrm{N}$ & 48 & 48 & 46 & 46 & 40 & 39 & 40 & 47 & 47 & 48 & 48 & 45 & 47 & 48 & 48 & 48 \\
\hline \multicolumn{17}{|c|}{ All family banks } \\
\hline Mean & 1.801 & 11.626 & 4.265 & 3.862 & 46.013 & 5.158 & 41.348 & 1.350 & 9.459 & 3.763551 & 6626 & 10.297 & 15.274 & 0.022 & 0.483 & 0.857 \\
\hline SD & 2.686 & 12.095 & 5.170 & 5.379 & 67.585 & 5.570 & 64.670 & 1.949 & 18.102 & 3.96236 & 25300 & 7.647 & 10.127 & 0.148 & 0.500 & 0.351 \\
\hline Min & -10.660 & -36.020 & -1.836 & -1.622 & 0.070 & 0.008 & 0.665 & 0.031 & 0.079 & 0 & 11.76 & 0.336 & 3.141 & 0 & 0 & 0 \\
\hline Median & 1.630 & 10.420 & 2.763 & 2.513 & 26.647 & 3.173 & 22.382 & 0.644 & 4.226 & 2.56 & 558.8 & 7.805 & 12.148 & 0 & 0 & 1 \\
\hline Max & 15.210 & 64.510 & 31.283 & 51.845 & 641.869 & 32.143 & 625.939 & 17.121 & 191.933 & 23.17 & 245000 & 41.958 & 51.069 & 1 & 1 & 1 \\
\hline $\mathrm{N}$ & 356 & 347 & 346 & 345 & 267 & 246 & 267 & 355 & 354 & 352 & 356 & 347 & 347 & 356 & 356 & 356 \\
\hline \multicolumn{17}{|l|}{ Total } \\
\hline Mean & 2.642 & 17.983 & 4.869 & 4.752 & 39.517 & 5.957 & 33.263 & 1.394 & 10.484 & 4.782392 & 13500 & 15.873 & 13.104 & 0.210 & 0.583 & 0.435 \\
\hline SD & 2.419 & 14.550 & 5.062 & 6.391 & 90.112 & 6.199 & 74.618 & 2.507 & 17.784 & 6.439887 & 37600 & 13.932 & 8.928 & 0.407 & 0.493 & 0.496 \\
\hline Min & -10.660 & -36.020 & -1.836 & -1.622 & 0.070 & 0.008 & 0.140 & 0.012 & 0.059 & 0 & 11.76 & 0.336 & 0.260 & 0 & 0 & 0 \\
\hline Median & 2.455 & 15.670 & 3.405 & 2.788 & 23.161 & 4.054 & 18.293 & 0.764 & 5.130 & 2.9 & 1997.6 & 10.755 & 10.383 & 0 & 1 & 0 \\
\hline Max & 15.210 & 69.930 & 31.283 & 58.962 & 1848.302 & 56.024 & 1449.642 & 49.195 & 191.933 & 47.39 & 338000 & 65.250 & 52.942 & 1 & 1 & 1 \\
\hline $\mathrm{N}$ & 838 & 822 & 819 & 815 & 628 & 597 & 622 & 835 & 825 & 832 & 840 & 828 & 817 & 840 & 840 & 840 \\
\hline
\end{tabular}

Panel B. t-test of difference in means

\section{Bank groups compared}

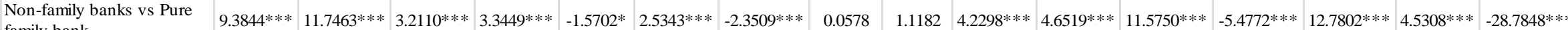

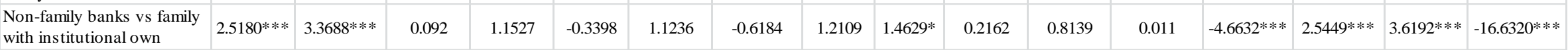

\begin{tabular}{|l|l|l|l|l|l|l|l|l|l|l|l|l|l|l|l|l|l|l} 
Family with institutional & $1.8995 * *$ & $2.2242 * *$ & $1.3768 *$ & 0.4476 & -0.5769 & 0.1726 & -0.6542 & $-1.6262 *$ & -0.8091 & $2.8933 * * *$ & $1.9744 * *$ & $10.2718^{* * *}$ & $1.3356 *$ & $7.8265 * * *$ & $-1.3009 *$ & 0.8065
\end{tabular}

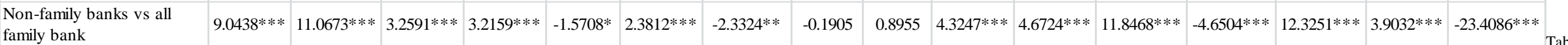
family bank

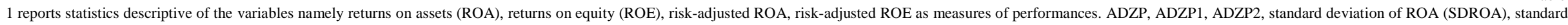

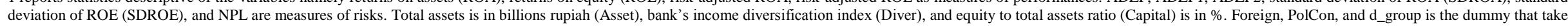

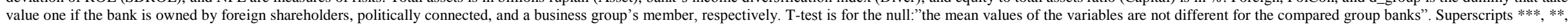
and * denotes statistical significant at the $.01, .05$ and .10 levels respectively. See Appendix A for the details. 
Table 2. Correlation matrix

\begin{tabular}{|c|c|c|c|c|c|c|c|c|c|c|c|c|c|c|c|c|c|c|c|c|c|c|}
\hline & ROA & ROE & $\operatorname{adjROA}$ & adjROE & ADZP & ADZP1 & ADZP2 & SDROA & SDROE & NPL & Family & Fam_direct & Fam_only I & Family_with_inst & PolCon & Listed & Size & Diver & Capital & $\mathrm{HHI}$ & Foreign & d_group \\
\hline ROA & 1 & & & & & & & & & & & & & & & & & & & & & \\
\hline ROE & $0.6447 *$ & 1 & & & & & & & & & & & & & & & & & & & & \\
\hline $\operatorname{adjROA}$ & $0.3082^{*}$ & $0.2918^{*}$ & 1 & & & & & & & & & & & & & & & & & & & \\
\hline adjROE & $0.2354 *$ & $0.2303^{*}$ & $0.4537^{*}$ & 1 & & & & & & & & & & & & & & & & & & \\
\hline ADZP & 0.0422 & -0.0612 & $0.6272^{*}$ & $0.3018^{*}$ & 1 & & & & & & & & & & & & & & & & & \\
\hline ADZP1 & $0.2521^{*}$ & 0.2993* & $0.7879^{*}$ & $0.4094^{*}$ & $0.7246^{*}$ & 1 & & & & & & & & & & & & & & & & \\
\hline ADZP2 & -0.0186 & $-0.1395^{*}$ & $0.5479 *$ & $0.2556^{*}$ & $0.9612^{*}$ & $0.6082 *$ & 1 & & & & & & & & & & & & & & & \\
\hline SDROA & -0.0516 & -0.0116 & $-0.3210^{*}$ & $-0.2122^{*}$ & $-0.6755^{*}$ & $-0.6207 *$ & $-0.5844^{*}$ & 1 & & & & & & & & & & & & & & \\
\hline SDROE & $-0.1697^{*}$ & 0.0509 & $-0.2706^{*}$ & $-0.2815^{*}$ & $-0.5488^{*}$ & $-0.4240^{*}$ & $-0.5076^{*}$ & $0.4928^{*}$ & 1 & & & & & & & & & & & & & \\
\hline NPL & $-0.0610^{*}$ & $-0.1608^{*}$ & $-0.2167^{*}$ & $-0.1675^{*}$ & $-0.2064^{*}$ & $-0.2228^{*}$ & $-0.1733^{*}$ & $0.2363^{*}$ & $0.2626^{*}$ & 1 & & & & & & & & & & & & \\
\hline Family & $-0.2974^{*}$ & $-0.3729^{*}$ & $-0.1021 *$ & $-0.1193^{*}$ & $0.1187^{*}$ & $-0.1685^{*}$ & $0.1872^{*}$ & -0.0151 & -0.05 & $-0.1356^{*}$ & 1 & & & & & & & & & & & \\
\hline Fam_direct & $-0.2684 *$ & $-0.3150^{*}$ & $-0.1922^{*}$ & $-0.1765^{*}$ & $-0.0747 *$ & $-0.2921^{*}$ & -0.0166 & 0.0455 & 0.0503 & -0.0543 & $0.5852^{*}$ & 1 & & & & & & & & & & \\
\hline Fam_only & $-0.3043^{*}$ & $-0.3629^{*}$ & $-0.1133^{*}$ & $-0.1121^{*}$ & $0.0946^{*}$ & $-0.1644^{*}$ & $0.1601^{*}$ & 0.0066 & -0.0312 & $-0.1484 *$ & $0.8872^{*}$ & $0.6411^{*}$ & 1 & & & & & & & & & \\
\hline Family_with_inst & -0.0012 & -0.0411 & 0.0179 & -0.0214 & 0.0544 & -0.0191 & 0.0636 & -0.0462 & -0.0417 & 0.0193 & $0.2870^{*}$ & $-0.0852^{*}$ & $-0.1873^{*}$ & 1 & & & & & & & & \\
\hline PolCon & 0.0362 & $0.3508^{*}$ & $0.1488^{*}$ & $0.1801^{*}$ & 0.0399 & $0.1765^{*}$ & 0.0109 & $-0.0623^{*}$ & 0.0117 & $-0.1685^{*}$ & $-0.1743^{*}$ & $-0.1421^{*}$ & $-0.1336^{*}$ & $-0.0936^{*}$ & 1 & & & & & & & \\
\hline Listed & $-0.1997^{*}$ & -0.0535 & -0.0201 & -0.0046 & -0.0112 & -0.0559 & 0.0081 & -0.0187 & -0.0467 & $0.0719 *$ & $0.0874^{*}$ & -0.0432 & 0.0545 & $0.0728^{*}$ & $0.1814^{*}$ & 1 & & & & & & \\
\hline Size & $0.1318^{*}$ & $0.3181 *$ & $0.1629 *$ & $0.1254^{*}$ & 0.0091 & $0.2294 *$ & $-0.0693^{*}$ & $-0.1119^{*}$ & -0.0487 & 0.055 & $-0.4631 *$ & $-0.4818^{*}$ & $-0.5316^{*}$ & $0.1177^{*}$ & $0.1991^{*}$ & $0.4179 *$ & 1 & & & & & \\
\hline Diver & $0.1415^{*}$ & 0.0129 & $-0.1091^{*}$ & $-0.1240^{*}$ & $-0.2493^{*}$ & $-0.0912^{*}$ & $-0.2729 *$ & $0.0703^{*}$ & $0.1243^{*}$ & $0.3192 *$ & $-0.3314^{*}$ & $-0.2813^{*}$ & $-0.3772^{*}$ & $0.0789^{*}$ & $-0.3278^{*}$ & 0.0175 & $0.3827^{*}$ & 1 & & & & \\
\hline Capital & $0.2760^{*}$ & $-0.2382^{*}$ & -0.008 & -0.0217 & $0.1827^{*}$ & $-0.0760^{*}$ & $0.2414 *$ & $0.0652^{*}$ & $-0.1391^{*}$ & 0.0408 & $0.2076^{*}$ & $0.1304^{*}$ & $0.1591^{*}$ & $0.1113^{*}$ & $-0.3189^{*}$ & $-0.2075^{*}$ & $-0.3965^{*}$ & -0.0278 & 1 & & & \\
\hline HHI & -0.0043 & $0.1457^{*}$ & $-0.1778^{*}$ & $-0.1683^{*}$ & $-0.1637^{*}$ & $-0.1050^{*}$ & $-0.1539 *$ & $0.2830^{*}$ & $0.3236^{*}$ & $0.2177^{*}$ & -0.0032 & 0.0099 & 0.0303 & $-0.0697^{*}$ & -0.0219 & $-0.0854^{*}$ & $-0.1982^{*}$ & -0.0049 & $-0.0968^{*}$ & 1 & & \\
\hline Foreign & $0.2146^{*}$ & $-0.0719^{*}$ & $-0.0989 *$ & $-0.0746^{*}$ & $-0.1402^{*}$ & -0.0653 & $-0.1659^{*}$ & $0.0608^{*}$ & $0.0684^{*}$ & $0.3087^{*}$ & $-0.3942 *$ & $-0.2584^{*}$ & $-0.3917 *$ & -0.0259 & $-0.4608^{*}$ & $-0.2263^{*}$ & $0.1764^{*}$ & $0.7159^{*}$ & $0.1270^{*}$ & 0 & 1 & \\
\hline d_group & $-0.2536^{*}$ & $-0.3302^{*}$ & $-0.0847^{*}$ & $-0.0924 *$ & $0.1133^{*}$ & $-0.1270^{*}$ & $0.1698^{*}$ & -0.0564 & $-0.1011^{*}$ & $-0.1011^{*}$ & $0.7305^{*}$ & $0.3628^{*}$ & $0.6288^{*}$ & $0.2498^{*}$ & $-0.1311^{*}$ & $0.3254^{*}$ & $-0.2073^{*}$ & $-0.2761^{*}$ & $0.1300^{*}$ & -0.0178 & $-0.4041^{*}$ & 1 \\
\hline Covdep & -0.0068 & -0.0132 & -0.0236 & -0.0298 & $-0.0750^{*}$ & -0.0614 & $-0.0741^{*}$ & -0.0236 & -0.0226 & $-0.0681^{*}$ & 0.0089 & 0.0192 & 0.0272 & -0.0376 & 0.0049 & 0.0076 & 0.0112 & -0.0354 & -0.0381 & $-0.1973^{*}$ & 0 & 0.0016 \\
\hline
\end{tabular}

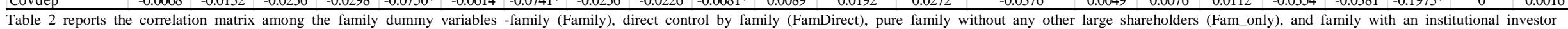

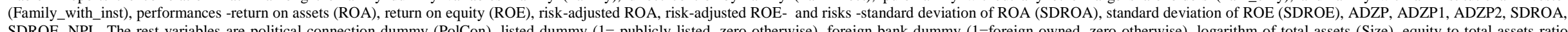

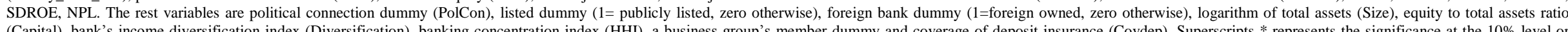

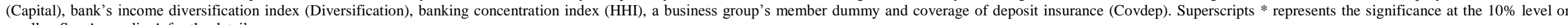
smaller. See Appendix A for the details. 
Table 3. The effect of family ownership on bank performance

\begin{tabular}{|c|c|c|c|c|c|c|c|c|c|c|c|c|c|c|c|c|}
\hline \multirow{2}{*}{$\begin{array}{c}\text { Dependent } \\
\text { var. }\end{array}$} & \multicolumn{4}{|c|}{ Panel A } & \multicolumn{4}{|c|}{ Panel B } & \multicolumn{4}{|c|}{ Panel C } & \multicolumn{4}{|c|}{ Panel D } \\
\hline & ROA & ROE & adj ROA & adj ROE & ROA & ROE & adj ROA & adj ROE & ROA & ROE & adj ROA & adj ROE & ROA & ROE & adj ROA & adj ROE \\
\hline Model & (1) & (2) & (3) & (4) & (1) & (2) & (3) & (4) & (1) & (2) & (3) & (4) & (1) & (2) & (3) & (4) \\
\hline \multirow[t]{2}{*}{ Family } & $-0.0882^{* * * *}$ & $-0.630 * * *$ & $-14.52^{* * * *}$ & $-10.95^{* * *}$ & & & & & & & & & & & & \\
\hline & $(-3.33)$ & $(-3.40)$ & $(-2.64)$ & $(-2.53)$ & & & & & & & & & & & & \\
\hline \multirow[t]{2}{*}{ Fam_direct } & & & & & $-0.0671 * * *$ & $-0.456^{* * * *}$ & $-9.805 * * *$ & $-8.461 * * *$ & & & & & & & & \\
\hline & & & & & $(-3.77)$ & $(-3.94)$ & $(-3.54)$ & $(-2.96)$ & & & & & & & & \\
\hline \multirow[t]{2}{*}{ Family_only } & & & & & & & & & $-0.0665^{* * * *}$ & $-0.466^{* * * *}$ & $-10.20 * * *$ & $-8.122 * * *$ & & & & \\
\hline & & & & & & & & & $(-4.08)$ & $(-4.39)$ & $(-3.14)$ & $(-2.85)$ & & & & \\
\hline \multirow{2}{*}{$\begin{array}{l}\text { Family_with } \\
\text { _inst. }\end{array}$} & & & & & & & & & & & & & $0.266^{* *}$ & $1.780^{* *}$ & $32.46 * *$ & $32.88^{* * *}$ \\
\hline & & & & & & & & & & & & & (2.37) & (2.45) & (2.44) & (2.15) \\
\hline \multirow[t]{2}{*}{ PolCon } & $-0.0174 * *$ & $-0.120^{* *}$ & $-4.165^{* *}$ & -2.090 & -0.000135 & 0.00861 & $-1.198^{*}$ & 0.141 & -0.00538 & -0.0316 & $-2.106^{* *}$ & -0.600 & $0.0313^{* * *}$ & $0.222 * * *$ & $2.752^{* * *}$ & $3.893^{* *}$ \\
\hline & $(-2.03)$ & $(-1.99)$ & $(-2.30)$ & $(-1.42)$ & $(-0.04)$ & (0.34) & $(-1.90)$ & $(0.21)$ & $(-1.21)$ & $(-1.09)$ & $(-2.35)$ & $(-0.70)$ & (2.81) & (3.05) & (2.05) & (2.47) \\
\hline \multirow[t]{2}{*}{ Listed } & 0.0109 & 0.0816 & 2.456 & 1.959 & $-0.00670^{*}$ & $-0.0504^{*}$ & -0.710 & -0.348 & 0.00448 & 0.0348 & 1.133 & 1.003 & $-0.0145 *$ & -0.0952 & $-1.888^{*}$ & -1.587 \\
\hline & (1.19) & (1.30) & (1.23) & (1.20) & $(-1.65)$ & $(-1.86)$ & $(-0.92)$ & $(-0.43)$ & $(0.74)$ & $(0.87)$ & $(0.81)$ & $(0.82)$ & $(-1.65)$ & $(-1.55)$ & $(-1.67)$ & $(-1.22)$ \\
\hline \multirow[t]{2}{*}{ Size } & $-0.00587^{*}$ & $-0.0389^{*}$ & -0.979 & -0.640 & -0.00318 & -0.0139 & -0.327 & -0.290 & $-0.00493^{*}$ & $-0.0307^{*}$ & -0.695 & -0.478 & -0.00215 & -0.00859 & -0.0100 & -0.0962 \\
\hline & $(-1.77)$ & $(-1.72)$ & $(-1.43)$ & $(-1.20)$ & $(-1.44)$ & $(-1.04)$ & $(-1.00)$ & $(-0.88)$ & $(-1.96)$ & $(-1.94)$ & $(-1.38)$ & $(-1.12)$ & $(-0.65)$ & $(-0.40)$ & $(-0.02)$ & $(-0.23)$ \\
\hline \multirow[t]{2}{*}{ Capital } & $0.132^{* * * *}$ & 0.118 & $6.804 * *$ & 4.340 & $0.0854^{* * * *}$ & $-0.174 *$ & -0.578 & -0.940 & $0.106^{* * * *}$ & -0.0678 & 2.065 & 1.241 & 0.0223 & $-0.609^{*}$ & -7.936 & -8.147 \\
\hline & (6.66) & (1.12) & (2.02) & (1.59) & (4.59) & $(-1.72)$ & $(-0.21)$ & $(-0.33)$ & (6.09) & $(-0.79)$ & $(0.79)$ & $(0.48)$ & $(0.46)$ & $(-1.95)$ & $(-1.37)$ & $(-1.25)$ \\
\hline \multirow{2}{*}{ Diver } & 0.0129 & 0.0780 & -3.621 & $-9.874 * * *$ & 0.00124 & -0.0328 & $-5.813 * * *$ & $-11.02^{* * * *}$ & -0.00425 & -0.0524 & $-6.648 * * *$ & $-11.89 * * *$ & -0.0568 & $-0.428^{*}$ & $-13.71 * * *$ & $-18.24 * * *$ \\
\hline & $(0.78)$ & $(0.69)$ & $(-1.37)$ & $(-3.14)$ & $(0.11)$ & $(-0.44)$ & $(-3.09)$ & $(-3.83)$ & $(-0.36)$ & $(-0.66)$ & $(-3.39)$ & $(-3.93)$ & $(-1.62)$ & $(-1.80)$ & $(-3.15)$ & $(-3.29)$ \\
\hline \multirow[t]{2}{*}{ Foreign } & $-0.0390 * * *$ & $-0.361 * * *$ & $-8.310^{* * *}$ & $-4.161 *$ & -0.00666 & $-0.120 * * *$ & $-2.821 * * *$ & -0.216 & $-0.0190^{* *}$ & $-0.213^{* * *}$ & $-4.771 * * *$ & -1.720 & $0.0422^{* *}$ & 0.211 & 3.460 & $5.657^{* * *}$ \\
\hline & $(-2.61)$ & $(-3.62)$ & $(-2.87)$ & $(-1.85)$ & $(-1.25)$ & $(-3.95)$ & $(-3.30)$ & $(-0.18)$ & $(-2.40)$ & $(-4.53)$ & $(-3.39)$ & $(-1.21)$ & (2.16) & (1.63) & (1.49) & (2.02) \\
\hline \multirow[t]{2}{*}{ HHI } & -0.000679 & 0.00598 & $-0.806^{* * * *}$ & $-0.755^{* * * *}$ & -0.000166 & $0.0100^{*}$ & $-0.668 * * *$ & $-0.708^{* * *}$ & -0.0000489 & $0.0105^{* *}$ & $-0.678^{* * * *}$ & $-0.675^{* * *}$ & 0.00175 & $0.0214 * *$ & $-0.392 * *$ & $-0.493 * *$ \\
\hline & $(-0.62)$ & $(0.84)$ & $(-3.73)$ & $(-4.05)$ & $(-0.20)$ & $(1.92)$ & $(-4.65)$ & $(-4.48)$ & $(-0.06)$ & $(2.08)$ & $(-4.27)$ & $(-4.30)$ & $(1.31)$ & $(2.32)$ & $(-2.36)$ & $(-2.45)$ \\
\hline \multirow[t]{2}{*}{ Constant } & $0.154 * *$ & $1.075^{* *}$ & $35.70 * *$ & $27.94 * *$ & $0.0798^{*}$ & $0.450^{*}$ & $19.73 * * *$ & $18.57 * * *$ & $0.118^{* * *}$ & $0.792^{* * *}$ & 27.40 *** & $22.73 * * *$ & 0.0105 & 0.0184 & 7.706 & 9.248 \\
\hline & $(2.20)$ & $(2.26)$ & $(2.46)$ & (2.43) & (1.84) & (1.70) & $(3.08)$ & $(2.77)$ & (2.38) & (2.55) & $(2.76)$ & (2.62) & $(0.24)$ & $(0.06)$ & (1.41) & (1.54) \\
\hline No. obs & 795 & 781 & 780 & 776 & 795 & 781 & 780 & 776 & 795 & 781 & 780 & 776 & 795 & 781 & 780 & 776 \\
\hline F-stat & $9.345^{* * * *}$ & $14.65^{* * * *}$ & $5.931 * * *$ & $6.694 \quad * * *$ & $14.39 * * *$ & $20.85^{* * * *}$ & $9.849 * * *$ & $7.916 * * *$ & $13.62^{* * * *}$ & $19.92 * * *$ & $8.775^{* * *}$ & $7.524 * * *$ & $3.354 * * *$ & $5.417 * * *$ & $5.810 * * *$ & $4.327 * * *$ \\
\hline Hansen J-stat & 0.137 & 0.286 & 2.089 & 0.454 & 0.177 & 0.426 & $3.952^{* * *}$ & 0.491 & 0.445 & 0.811 & $4.488^{* * *}$ & 0.847 & 0.447 & 0.607 & $5.754 * *$ & 1.069 \\
\hline Endog. test & $24.197 * * *$ & $29.024 * * *$ & $13.182^{* * * *}$ & $7.876^{* * * *}$ & $20.269^{* * * *}$ & $26.809 * * *$ & $10.084 * * *$ & $4.946 * *$ & $22.256^{* * *}$ & $26.509 * * *$ & $10.856^{* * * *}$ & $7.439 * * * *$ & $25.502^{* * * *}$ & $31.096^{* * * *}$ & $6.839 * * *$ & $8.081^{* * * *}$ \\
\hline
\end{tabular}


Table 4. The effect of family ownership on bank risk

\begin{tabular}{|c|c|c|c|c|c|c|c|c|c|c|c|c|c|c|c|c|c|c|c|c|c|c|c|c|}
\hline \multirow{2}{*}{\begin{tabular}{|c|}
$\begin{array}{c}\text { Dependent } \\
\text { var. }\end{array}$ \\
\end{tabular}} & \multicolumn{6}{|c|}{ Panel A } & \multicolumn{6}{|c|}{ Panel B } & \multicolumn{6}{|c|}{ Panel C } & \multicolumn{6}{|c|}{ Panel D } \\
\hline & ADZP & ADZP1 & ADZP2 & SDROA & SDROE & NPL & ADZP & ADZP1 & ADZP2 & SDROA & SDROE & NPL & ADZP & ADZP1 & ADZP2 & SDROA & SDROE & NPL & ADZP & ADZP1 & ADZP2 & SDROA & SDROE & NPL \\
\hline Model & (1) & (2) & (3) & (4) & (5) & (6) & (1) & (2) & (3) & (4) & (5) & (6) & (1) & (2) & (3) & (4) & (5) & (6) & (1) & (2) & (3) & (4) & (5) & (6) \\
\hline \multirow[t]{2}{*}{ Family } & $\mid-0.939^{* * *}$ & $-2.296^{* *}$ & \begin{tabular}{|c|}
$-0.807 * *$ \\
\end{tabular} & $0.773 * *$ & $1.002 * * *$ & 0.452 & & & & & & & & & & & & & & & & & & \\
\hline & $(-2.63)$ & $(-2.03)$ & $(-2.25)$ & (2.55) & (3.29) & (1.61) & & & & & & & & & & & & & & & & & & \\
\hline Fam_direct & & & & & & & $(-4.19)$ & $(-2.59)$ & $(-4.59)$ & $(4.14)$ & $(4.46)$ & (3.16) & & & & & & & & & & & & \\
\hline \multirow[t]{2}{*}{ Family only } & & & & & & & & & & & & & $-0.813^{* * * *}$ & $-1.608^{* * * *}$ & $-0.700 * *$ & $0.694^{* * * *}$ & $0.882^{* * * *}$ & $0.407 *$ & & & & & & \\
\hline & & & & & & & & & & & & & $(-2.65)$ & $(-4.73)$ & $(-2.27)$ & (2.62) & (3.27) & (1.68) & & & & & & \\
\hline \multirow{2}{*}{$\begin{array}{l}\text { Family_with_} \\
\text { inst }\end{array}$} & & & & & & & & & & & & & & & & & & & $0.974^{* *}$ & $10.24 * *$ & $1.287 * * *$ & $-0.836^{*}$ & $-7.160 * *$ & $-1.022 * *$ \\
\hline & & & & & & & & & & & & & & & & & & & (2.19) & (2.48) & $(2.76)$ & $(-1.96)$ & $(-2.14)$ & $(-2.16)$ \\
\hline \multirow[t]{2}{*}{ PolCon } & $-0.385^{* *}$ & -0.674 & $-0.367^{* *}$ & $0.396 * * *$ & $0.558^{* * *}$ & 0.0158 & $-0.278^{* * * *}$ & -0.173 & $-0.306 * * *$ & $0.329 * * *$ & $0.406 * * *$ & 0.00219 & -0.279 ** & $-0.288^{* *}$ & $-0.275 * *$ & $0.319 * * *$ & $0.436^{* * * *}$ & -0.0473 & -0.0223 & $1.084^{* *}$ & -0.0103 & 0.0939 & -0.369 & $-0.224 * *$ \\
\hline & $(-2.47)$ & $(-1.62)$ & $(-2.33)$ & $(2.78)$ & (3.82) & $(0.12)$ & $(-2.75)$ & $(-1.10)$ & $(-2.92)$ & (3.34) & (3.84) & $(0.02)$ & $(-2.18)$ & $(-2.03)$ & $(-2.16)$ & $(2.70)$ & (3.55) & $(-0.43)$ & $(-0.20)$ & $(2.55)$ & $(-0.09)$ & $(0.90)$ & $(-1.25)$ & $(-2.16)$ \\
\hline \multirow[t]{2}{*}{ Listed } & 0.217 & 0.273 & $0.363^{*}$ & -0.262 & $-0.410^{* *}$ & $0.402 * * *$ & 0.0728 & $-0.326^{*}$ & $0.270^{* *}$ & -0.130 & $-0.232^{*}$ & $0.428^{* * *}$ & 0.165 & -0.0230 & $0.318^{*}$ & -0.208 & $-0.361^{* *}$ & $0.416^{* * *}$ & -0.102 & $-0.790^{*}$ & 0.0666 & -0.00165 & -0.0979 & $0.557^{* * *}$ \\
\hline & (1.05) & $(0.58)$ & (1.77) & $(-1.52)$ & $(-2.48)$ & $(2.64)$ & $(0.54)$ & $(-1.92)$ & $(1.97)$ & $(-1.02)$ & $(-1.90)$ & $(3.48)$ & $(0.87)$ & $(-0.11)$ & (1.69) & $(-1.25)$ & $(-2.28)$ & $(2.84)$ & $(-0.73)$ & $(-1.68)$ & $(0.45)$ & $(-0.01)$ & $(-0.35)$ & $(4.40)$ \\
\hline \multirow[t]{2}{*}{ Size } & 0.0122 & -0.0747 & -0.0132 & 0.0260 & $0.0990 * *$ & 0.0362 & -0.0147 & 0.00705 & -0.0606 & 0.0466 & $0.0981^{* *}$ & $0.0791^{*}$ & 0.00704 & -0.0260 & -0.0174 & 0.0271 & $0.0968^{*}$ & 0.0401 & $0.104 * * *$ & -0.0357 & 0.0567 & -0.0496 & 0.160 & 0.00152 \\
\hline & $(0.19)$ & $(-0.49)$ & $(-0.20)$ & $(0.54)$ & $(2.02)$ & $(0.73)$ & $(-0.27)$ & $(0.08)$ & $(-1.18)$ & (1.14) & (2.49) & $(1.88)$ & $(0.11)$ & $(-0.41)$ & $(-0.26)$ & $(0.53)$ & $(1.90)$ & $(0.79)$ & $(2.68)$ & $(-0.26)$ & $(1.50)$ & $(-1.55)$ & (1.56) & $(0.05)$ \\
\hline \multirow[t]{2}{*}{ Capital } & $2.919 * * *$ & 0.649 & $3.478^{* * *}$ & $2.237^{* * * *}$ & $-1.381 * *$ & $0.986^{*}$ & $2.190 * * *$ & -0.264 & $2.759^{* * * *}$ & $2.967^{* * * *}$ & -0.665 & $1.420 * * *$ & $2.593^{* * * *}$ & 0.0161 & $3.199^{* * * *}$ & $2.561^{* * * *}$ & $-1.059^{*}$ & $1.124 * *$ & $2.400 * * *$ & -3.273 & $2.891^{* * *}$ & $2.723 * * *$ & 1.428 & $1.475^{* * * *}$ \\
\hline & $(4.37)$ & (0.84) & $(4.78)$ & (3.99) & $(-2.23)$ & (1.86) & (3.25) & $(-0.38)$ & (3.70) & (5.17) & $(-1.09)$ & $(2.61)$ & (3.91) & $(0.02)$ & (4.40) & (4.67) & $(-1.75)$ & (2.11) & (3.81) & $(-1.61)$ & (4.17) & (5.03) & $(0.89)$ & (2.78) \\
\hline \multirow[t]{2}{*}{ Diver. } & $-2.777 * * *$ & $-1.479 * *$ & $-3.122^{* * * *}$ & $1.440^{* * * *}$ & $2.834 * * *$ & $1.555^{* * * *}$ & $-2.733^{* * * *}$ & $-1.721^{* * * *}$ & $-3.067 * * *$ & $1.518^{* * * *}$ & $3.009 * * *$ & $1.498 * * *$ & $-2.914 * * *$ & $-1.931 * * *$ & $-3.246 * * * *$ & $1.616^{* * * *}$ & $3.147 * * *$ & $1.555^{* * * *}$ & $-3.094 * * *$ & $-3.918 * *$ & $-3.436^{* * * *}$ & $1.745 * * *$ & $4.468 * * *$ & $1.861^{* * * *}$ \\
\hline & $(-4.39)$ & $(-2.03)$ & $(-4.97)$ & (3.06) & (5.13) & (3.12) & $(-4.37)$ & $(-3.05)$ & $(-4.81)$ & (3.19) & $(5.55)$ & $(3.06)$ & $(-4.80)$ & $(-3.53)$ & $(-5.42)$ & (3.44) & (5.78) & $(3.15)$ & $(-5.21)$ & $(-2.42)$ & $(-5.75)$ & (3.62) & (3.95) & (3.63) \\
\hline \multirow[t]{2}{*}{ HHI } & $-0.173^{* * *} \mid$ & $-0.161^{* *}$ & $-0.177^{* * * *}$ & $0.168^{* * * *}$ & $0.273^{* * *}$ & $0.137 * * *$ & $-0.178 * * * \mid$ & $-0.143 * *$ & $-0.187 * * *$ & $0.172 * * *$ & $0.285^{* * *}$ & $0.141 * * *$ & $-0.164 * * *$ & $-0.128^{* * *}$ & $-0.169 * * *$ & $0.163^{* * * *}$ & $0.273^{* * *}$ & $0.130^{* * *}$ & $-0.139 * * *$ & -0.0340 & $-0.145^{* * * *}$ & $0.146 * * *$ & $0.230 * * *$ & $0.117^{* * * *}$ \\
\hline & $(-2.98)$ & $(-2.13)$ & $(-2.92)$ & $(4.04)$ & $(5.95)$ & $(3.43)$ & $(-3.32)$ & $(-2.48)$ & $(-3.25)$ & $(4.44)$ & $(6.70)$ & $(3.64)$ & $(-2.95)$ & $(-2.15)$ & $(-2.91)$ & $(4.05)$ & $(6.14)$ & $(3.28)$ & $(-2.68)$ & $(-0.25)$ & $(-2.61)$ & $(3.85)$ & $(3.33)$ & $(2.98)$ \\
\hline \multirow[t]{2}{*}{ Covdep } & $\mid-0.122 * *$ & $-0.140^{* *}$ & $-0.138^{* *}$ & $0.114^{* *}$ & $0.140^{* *}$ & 0.0272 & $\mid-0.118^{* *}$ & $-0.135^{* *}$ & $-0.134 * *$ & $0.114^{* *}$ & $0.147 * * *$ & 0.0259 & $-0.117^{* *}$ & $-0.122^{*}$ & $-0.133^{*} *$ & $0.114 * *$ & $0.144 * *$ & 0.0196 & $-0.113^{* *}$ & -0.0609 & $-0.128^{* * *}$ & $0.112^{* *}$ & 0.118 & 0.0156 \\
\hline & $(-2.27)$ & $(-1.98)$ & $(-2.50)$ & $(2.28)$ & (2.46) & $(0.54)$ & $(-2.37)$ & $(-2.42)$ & $(-2.55)$ & (2.44) & $(2.76)$ & $(0.52)$ & $(-2.20)$ & $(-1.93)$ & $(-2.46)$ & $(2.28)$ & (2.53) & $(0.39)$ & $(-2.18)$ & $(-0.42)$ & $(-2.35)$ & $(2.28)$ & (1.20) & $(0.30)$ \\
\hline \multirow[t]{2}{*}{ Constant } & $5.507 * * *$ & $6.076^{*}$ & $5.637^{* * *}$ & $-3.871^{* * * *}$ & $-3.735^{* * *}$ & $-6.109^{* * * *}$ & $5.776 * * *$ & $3.893 * *$ & $6.342 * * *$ & $-4.143 * * *$ & $-3.636^{* * * *}$ & $-6.763^{* * * *}$ & $5.360^{* * * *}$ & $4.475^{* * *}$ & $5.516^{* * * *}$ & $-3.778^{* * *}$ & $-3.591^{* * * *}$ & $-6.001 * * *$ & $3.220^{* * *}$ & 2.023 & $3.740^{* * * *}$ & $-2.064 * * *$ & $-3.153^{* * *}$ & $-5.046^{* * *}$ \\
\hline & (3.89) & (1.84) & (3.91) & $(-3.52)$ & $(-3.41)$ & $(-5.58)$ & (5.32) & $(2.22)$ & (5.90) & $(-4.86)$ & $(-4.30)$ & $(-7.60)$ & $(4.00)$ & (3.38) & $(4.01)$ & $(-3.52)$ & $(-3.35)$ & $(-5.57)$ & (3.93) & $(0.90)$ & (4.44) & $(-3.05)$ & $(-2.01)$ & $(-7.11)$ \\
\hline No. obs. & 599 & 575 & 597 & 699 & 698 & 677 & 599 & 575 & 597 & 699 & 698 & 677 & 599 & 575 & 597 & 699 & 698 & 677 & 599 & 575 & 597 & 699 & 698 & 677 \\
\hline F-stat & $7.344 * * *$ & $6.364^{* * * *}$ & $7.323^{* * *}$ & $12.03^{* * *}$ & $11.75^{* * *}$ & $12.68 * * *$ & $9.561^{* * *}$ & $7.957^{* * *}$ & $9.682^{* * * *}$ & $14.23^{* * * *}$ & $14.72 * * *$ & $13.33 * * *$ & $7.655^{* * * *}$ & $8.914^{* * *}$ & $7.776^{* * * *}$ & $13.15^{* * *}$ & $12.48^{* * * *}$ & $11.98 * * *$ & $7.490^{* * * *}$ & $2.854^{* * * *}$ & $7.701^{* * * *}$ & $13.73 * * *$ & $4.064 * * *$ & $12.29 * * *$ \\
\hline Hansen J-stat & 0.082 & 0.182 & 0.000 & 1.388 & 3.440 & 4.408 & 0.183 & 0.262 & 0.075 & 1.438 & 0.142 & 3.372 & 0.035 & 0.510 & 0.001 & 0.353 & 0.010 & 2.886 & 0.351 & 0.626 & 0.115 & 0.597 & 0.432 & 1.707 \\
\hline Endog. test & $13.206 * * *$ & $6.650^{* * * *}$ & $11.988^{* * * *}$ & $12.781^{* * * *}$ & $17.319^{* * *}$ & $5.622 * *$ & $13.455^{* * *}$ & $3.740 *$ & $17.574 * * *$ & $11.684 * * *$ & $10.742^{* * *}$ & $8.536 * * *$ & $13.596 * * *$ & $29.005 * * *$ & $12.483^{* * *}$ & $14.160^{* * * *}$ & $17.570 * * *$ & $9.995 * * *$ & $4.127 * *$ & $24.077 * * *$ & $6.885^{* * *}$ & $3.228^{*}$ & $10.174 * * *$ & $9.572 * * *$ \\
\hline
\end{tabular}

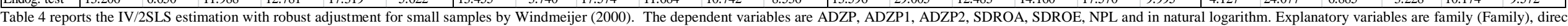

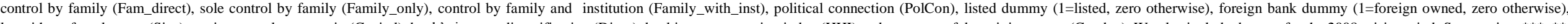

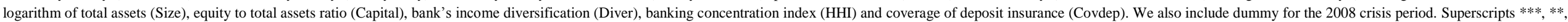
and * denotes statistical significant at the $.01, .05$ and .10 levels respectively. t-statistics shown in parentheses are corrected for White heteroskedasticity. 
Table 5. Family directors and bank performance and risk

\begin{tabular}{|c|c|c|c|c|c|c|c|c|c|c|}
\hline \multirow{2}{*}{ Dependent var. } & \multicolumn{4}{|c|}{ Panel A. Performance } & \multicolumn{6}{|c|}{ Panel B. Risk } \\
\hline & ROA & ROE & $\operatorname{adj} \mathrm{ROA}$ & adj ROE & ADZP & ADZP1 & ADZP2 & SDROA & SDROE & NPL \\
\hline Model & (1) & (2) & (3) & (4) & (1) & (2) & (3) & (4) & (5) & (6) \\
\hline \multirow[t]{2}{*}{ Family director } & $-0.0633 * * *$ & $-0.498 * * *$ & $-10.36 * * *$ & $-7.885 * *$ & $-1.471 * *$ & $-2.799 * * *$ & $-1.268 *$ & $1.157 * *$ & $1.532 * * *$ & $0.686 *$ \\
\hline & $(-4.07)$ & $(-3.84)$ & $(-2.78)$ & $(-2.57)$ & $(-2.21)$ & $(-3.32)$ & $(-1.94)$ & $(2.17)$ & $(2.66)$ & $(1.75)$ \\
\hline \multirow[t]{2}{*}{ PolCon } & $-0.0108 * *$ & $-0.0734 *$ & $-2.757 * *$ & -0.947 & $-0.520 * *$ & $-0.848 * *$ & $-0.484 * *$ & $0.493 * *$ & $0.683 * * *$ & 0.0683 \\
\hline & $(-2.01)$ & $(-1.69)$ & $(-2.21)$ & $(-0.89)$ & $(-2.23)$ & $(-2.55)$ & $(-2.11)$ & $(2.51)$ & $(3.18)$ & $(0.45)$ \\
\hline \multirow[t]{2}{*}{ Listed } & -0.0000678 & 0.00319 & 0.345 & 0.320 & 0.266 & 0.206 & 0.406 & -0.258 & $-0.440 * *$ & $0.384 * *$ \\
\hline & $(-0.01)$ & $(0.08)$ & $(0.26)$ & $(0.29)$ & (1.04) & $(0.63)$ & (1.64) & $(-1.26)$ & $(-2.12)$ & $(2.40)$ \\
\hline \multirow[t]{2}{*}{ Size } & -0.00223 & -0.0108 & -0.177 & -0.0334 & -0.00662 & -0.0747 & -0.0293 & 0.0291 & 0.103 & 0.0414 \\
\hline & $(-1.41)$ & $(-0.82)$ & $(-0.45)$ & $(-0.11)$ & $(-0.08)$ & $(-0.78)$ & $(-0.37)$ & $(0.50)$ & (1.63) & $(0.80)$ \\
\hline \multirow[t]{2}{*}{ Capital } & $0.104 * * *$ & 0.0959 & $7.088 * *$ & $4.647^{*}$ & $3.030 * * *$ & 0.607 & $3.572 * * *$ & $2.159 * * *$ & $-1.552 * *$ & $0.949 *$ \\
\hline & $(6.71)$ & $(0.96)$ & (2.30) & (1.77) & $(4.05)$ & $(0.66)$ & $(4.60)$ & $(3.47)$ & $(-2.18)$ & (1.68) \\
\hline \multirow[t]{2}{*}{ Diver. } & -0.00366 & -0.0932 & $-7.672 * * *$ & $-12.51 * * *$ & $-3.253 * * *$ & $-2.113 * * *$ & $-3.545 * * *$ & $1.838 * * *$ & $3.457 * * *$ & $1.803 * * *$ \\
\hline & $(-0.28)$ & $(-0.97)$ & $(-3.27)$ & $(-3.87)$ & $(-4.65)$ & $(-2.79)$ & $(-5.29)$ & $(3.42)$ & $(5.15)$ & $(3.55)$ \\
\hline \multirow[t]{2}{*}{ Foreign } & 0.000565 & $-0.227 * * *$ & $-4.842 * * *$ & -1.674 & -0.359 & $-1.009 * *$ & -0.307 & $0.633 * *$ & 0.146 & $0.520 * *$ \\
\hline & $(0.83)$ & $(-3.94)$ & $(-2.95)$ & $(-1.09)$ & $(-1.18)$ & $(-2.42)$ & $(-1.06)$ & $(2.49)$ & $(0.50)$ & $(2.33)$ \\
\hline \multirow[t]{2}{*}{$\mathrm{HHI}$} & $-0.0190 * *$ & $0.0151 * * *$ & $-0.586 * * *$ & $-0.577 * * *$ & $-0.175 * * *$ & $-0.146 *$ & $-0.179 * * *$ & $0.165 * * *$ & $0.279 * * *$ & $0.136 * * *$ \\
\hline & $(-2.53)$ & $(2.86)$ & $(-3.78)$ & $(-3.81)$ & $(-2.65)$ & $(-1.84)$ & $(-2.68)$ & $(3.61)$ & $(5.35)$ & $(3.29)$ \\
\hline \multirow[t]{2}{*}{ Covdep } & & & & & $-0.130 * *$ & $-0.153 *$ & $-0.146^{* *}$ & $0.121 * *$ & $0.156 * *$ & 0.0293 \\
\hline & & & & & $(-2.10)$ & $(-1.81)$ & $(-2.38)$ & $(2.16)$ & $(2.39)$ & $(0.56)$ \\
\hline \multirow[t]{2}{*}{ Constant } & $0.0744 * *$ & $0.479 *$ & $18.93 * *$ & $15.05 * *$ & $6.078 * * *$ & $6.225 * * *$ & $6.146 * * *$ & $-4.104 * * *$ & $-4.148 * * *$ & $-6.293 * * *$ \\
\hline & $(2.23)$ & $(1.74)$ & $(2.28)$ & $(2.22)$ & $(3.43)$ & $(2.86)$ & $(3.46)$ & $(-3.05)$ & $(-2.92)$ & $(-5.33)$ \\
\hline No. obs. & 781 & 781 & 780 & 776 & 599 & 575 & 597 & 699 & 698 & 677 \\
\hline F-stat. & $11.11^{* * *}$ & $15.05^{* * *}$ & $7.806 * * *$ & $7.366 * * *$ & $6.150 * * *$ & $5.006 * * *$ & $6.788 * * *$ & $11.26 * * *$ & $10.06 * * *$ & $12.24 * * *$ \\
\hline Hansen J-stat & 1.909 & 0.515 & $3.227^{*}$ & 0.642 & 0.027 & 0.270 & 0.001 & 0.017 & 0.016 & 0.991 \\
\hline Endog. test & $26.548 * * *$ & $28.413 * * *$ & $12.020 * * *$ & $8.115^{* * *}$ & $12.359 * * *$ & $25.442 * * *$ & $10.343 * * *$ & $13.413 * * *$ & $19.929 * * *$ & $5.321 * *$ \\
\hline
\end{tabular}

Table 5 reports the IV/2SLS estimation with robust adjustment for small samples by Windmeijer (2000). The dependent variables are performance (ROA, ROE, adj ROA, adj ROE) and risk (ADZP, ADZP1, ADZP2, SDROA, SDROE, NPL). Explanatory variables are family director, political connection (PolCon), listed dummy (1=listed, zero otherwise), foreign bank dummy (1=foreign owned, zero otherwise), logarithm of total assets (Size), equity to total assets ratio (Capital), bank's income diversification (Diver), banking concentration index (HHI) and coverage of deposit insurance (Covdep). We also include dummy for the 2008 crisis period. Superscripts $* * *$, **, and * denotes statistical significant at the $.01, .05$ and .10 levels respectively. $t$-statistics shown in parentheses are corrected for White heteroskedasticity 
Table 6. Bank with family director(s) and institutional ownership, performance and risk

\begin{tabular}{|c|c|c|c|c|c|c|c|c|c|c|}
\hline \multirow{2}{*}{ Dependent var. } & \multicolumn{4}{|c|}{ Panel A. Performance } & \multicolumn{6}{|c|}{ Panel B. Risk } \\
\hline & ROA & ROE & adj ROA & adj ROE & ADZP & ADZP1 & ADZP2 & SDROA & SDROE & NPL \\
\hline Model & (1) & (2) & (3) & (4) & (1) & (2) & (3) & (4) & $(5)$ & (6) \\
\hline \multirow{2}{*}{$\begin{array}{l}\text { Family } \\
\text { director_with_inst }\end{array}$} & $0.174 * * *$ & $1.146^{* * *}$ & $61.42 * *$ & $69.15 * *$ & $3.535 * * *$ & $3.019 * * *$ & $4.128 * * *$ & $-3.287 * * *$ & $-3.524 * * *$ & $-2.214 * *$ \\
\hline & $(2.64)$ & $(2.61)$ & $(2.57)$ & $(2.48)$ & $(2.93)$ & $(2.77)$ & $(3.25)$ & $(-3.13)$ & $(-3.19)$ & $(-2.45)$ \\
\hline \multirow[t]{2}{*}{ PolCon } & $0.0248 * * *$ & $0.178 * * *$ & $5.959 * * *$ & $7.549 * * *$ & 0.174 & $0.404 * * *$ & 0.223 & -0.111 & -0.0628 & $-0.328 * * *$ \\
\hline & $(3.95)$ & $(4.45)$ & $(2.84)$ & (3.34) & (1.11) & (2.89) & $(1.43)$ & $(-0.83)$ & $(-0.45)$ & $(-2.73)$ \\
\hline \multirow[t]{2}{*}{ Listed } & $0.0148 * * *$ & $-0.0984 * * *$ & -1.897 & -1.533 & -0.122 & $-0.621 * * *$ & 0.0793 & -0.00327 & -0.0844 & $0.525 * * *$ \\
\hline & $(-3.41)$ & $(-3.37)$ & $(-1.07)$ & $(-0.81)$ & $(-0.64)$ & $(-2.93)$ & $(0.39)$ & $(-0.02)$ & $(-0.49)$ & $(3.75)$ \\
\hline \multirow[t]{2}{*}{ Size } & -0.000508 & 0.00552 & -0.673 & -0.982 & 0.0457 & $0.140 * * *$ & -0.0112 & 0.00688 & 0.0585 & 0.0414 \\
\hline & $(-0.27)$ & $(0.44)$ & $(-0.96)$ & $(-1.29)$ & $(0.87)$ & (3.48) & $(-0.21)$ & $(0.17)$ & (1.40) & (1.10) \\
\hline \multirow[t]{2}{*}{ Capital } & $0.0542 * *$ & -0.221 & -9.317 & -11.87 & $1.809 * *$ & -0.135 & $2.185 * * *$ & $3.214 * * *$ & -0.405 & $1.677 * * *$ \\
\hline & $(2.22)$ & $(-1.54)$ & $(-1.13)$ & $(-1.25)$ & (2.39) & $(-0.19)$ & $(2.60)$ & $(5.22)$ & $(-0.59)$ & $(2.88)$ \\
\hline \multirow[t]{2}{*}{ Diver } & -0.00807 & -0.105 & $-12.16^{* *}$ & $-18.37 * * *$ & $-3.189 * * *$ & $-2.215 * * *$ & $-3.478 * * *$ & $1.893 * * *$ & $3.401 * * *$ & $1.846^{* * *}$ \\
\hline & $(-0.53)$ & $(-1.02)$ & $(-2.24)$ & $(-2.96)$ & $(-4.75)$ & $(-3.68)$ & $(-4.99)$ & $(3.42)$ & $(5.50)$ & (3.51) \\
\hline \multirow[t]{2}{*}{ Foreign } & $0.0305 * * *$ & $0.125 *$ & $7.859 * *$ & $11.18 * * *$ & $0.600 * *$ & $0.502 * *$ & $0.649 * * *$ & -0.239 & $-0.889 * * *$ & -0.0515 \\
\hline & $(2.84)$ & $(1.81)$ & (2.04) & (2.67) & $(2.52)$ & (2.19) & (2.69) & $(-1.08)$ & $(-3.65)$ & $(-0.25)$ \\
\hline \multirow[t]{2}{*}{ HHI } & 0.00133 & $0.0192 * * *$ & -0.193 & $-0.602 * *$ & $-0.122 * *$ & -0.0834 & $-0.127 * *$ & $0.138 * * *$ & $0.248 * * *$ & $0.131 * * *$ \\
\hline & (1.62) & $(3.50)$ & $(-0.76)$ & $(-2.00)$ & $(-2.07)$ & $(-1.38)$ & $(-2.01)$ & $(3.32)$ & (5.33) & (3.15) \\
\hline \multirow[t]{2}{*}{ Covdep } & & & & & -0.0925 & -0.101 & -0.101 & $0.0992 *$ & $0.128 * *$ & 0.0222 \\
\hline & & & & & $(-1.53)$ & $(-1.56)$ & $(-1.58)$ & (1.77) & $(2.01)$ & $(0.42)$ \\
\hline \multirow[t]{2}{*}{ Constant } & -0.00552 & -0.158 & 13.14 & $20.10^{*}$ & $3.703 * * *$ & 0.435 & $4.297 * * *$ & $-2.621 * * *$ & $-2.022 * *$ & -1.087 \\
\hline & $(-0.21)$ & $(-0.89)$ & $(1.31)$ & (1.77) & (3.63) & $(0.46)$ & $(4.04)$ & $(-3.23)$ & $(-2.34)$ & $(-1.40)$ \\
\hline No. obs. & 687 & 689 & 687 & 684 & 598 & 573 & 592 & 699 & 698 & 681 \\
\hline F-stat. & $13.33 * * *$ & $20.36 * * *$ & $4.011 * * *$ & $4.092 * * *$ & $5.978 * * *$ & $6.329 * * *$ & $5.405 * * *$ & $10.72 * * *$ & $9.177 * * *$ & $12.23 * * *$ \\
\hline Hansen J-stat & $8.700 *$ & $9.845 *$ & 6.381 & 6.062 & 0.717 & 1.232 & 0.329 & 0.739 & 0.347 & 2.057 \\
\hline Endog. test & $9.334 * * *$ & $7.255 * * *$ & $16.820 * * *$ & $12.185 * * *$ & $17.588 * * *$ & $20.276 * * *$ & $23.152 * * *$ & $16.076 * * *$ & $19.334 * * *$ & $8.753 * * *$ \\
\hline
\end{tabular}


Table 7. Family indirect control and bank performance and risk

\begin{tabular}{|c|c|c|c|c|c|c|c|c|c|c|}
\hline \multirow{2}{*}{ Dependent var. } & \multicolumn{4}{|c|}{ Panel A. Performance } & \multicolumn{6}{|c|}{ Panel B. Risk } \\
\hline & ROA & $\mathrm{ROE}$ & adj ROA & adj ROE & $\mathrm{ADZP}$ & ADZP1 & ADZP2 & SDROA & SDROE & NPL \\
\hline Model & $(1)$ & $(2)$ & (3) & (4) & (1) & $(2)$ & (3) & $(4)$ & $(5)$ & $(6)$ \\
\hline \multirow[t]{2}{*}{ Fam_indirect } & $0.0494 * * *$ & $0.232 * *$ & $23.72 * * *$ & $36.05 * * *$ & $7.448 * * *$ & $3.508 * * *$ & $2.458 * * *$ & $-2.598 * * *$ & $-3.001 * * *$ & $-8.183 * * *$ \\
\hline & $(2.69)$ & $(2.39)$ & $(3.35)$ & $(3.47)$ & $(3.23)$ & $(3.27)$ & $(3.13)$ & $(-3.62)$ & $(-3.56)$ & $(-4.64)$ \\
\hline \multirow[t]{2}{*}{ PolCon } & $0.0181 * * *$ & $0.115 * * *$ & $4.452 * * *$ & $7.318 * * *$ & $1.075 * *$ & $0.750 * * *$ & 0.265 & -0.242 & -0.238 & $-1.381 * * *$ \\
\hline & $(4.64)$ & $(5.64)$ & $(3.27)$ & $(3.39)$ & $(2.33)$ & $(2.64)$ & $(1.46)$ & $(-1.41)$ & $(-1.17)$ & $(-3.12)$ \\
\hline \multirow[t]{2}{*}{ Listed } & $-0.0255 * * *$ & $-0.153 * * *$ & $-6.811 * * *$ & $-8.537 * * *$ & $-1.579 * *$ & $-1.398 * * *$ & $-0.368 *$ & $0.465 * *$ & $0.452 * *$ & $1.976 * * *$ \\
\hline & $(-5.87)$ & $(-6.14)$ & $(-3.58)$ & $(-2.98)$ & $(-2.53)$ & $(-4.17)$ & $(-1.80)$ & $(2.45)$ & (1.97) & $(3.85)$ \\
\hline \multirow[t]{2}{*}{ Size } & $0.00493 * * *$ & $0.0366 * * *$ & $1.017 * * *$ & $0.931 * *$ & $0.163^{*}$ & $0.253 * * *$ & $0.0664 *$ & $-0.0651 *$ & -0.0287 & -0.0433 \\
\hline & $(5.80)$ & $(8.38)$ & $(3.56)$ & $(2.04)$ & $(1.71)$ & $(4.63)$ & $(1.70)$ & $(-1.75)$ & $(-0.70)$ & $(-0.43)$ \\
\hline \multirow[t]{2}{*}{ Capital } & $0.102 * * *$ & -0.100 & -11.92 & $-21.09 * *$ & -1.939 & -0.880 & $2.072 * *$ & $3.869 * * *$ & 0.132 & $5.845 * * *$ \\
\hline & $(5.21)$ & $(-1.02)$ & $(-1.60)$ & $(-2.03)$ & $(-0.83)$ & $(-0.72)$ & $(2.19)$ & $(4.24)$ & $(0.13)$ & $(2.72)$ \\
\hline \multirow[t]{2}{*}{ Diver } & -0.00299 & -0.0179 & $-8.740 * *$ & $-14.72 * *$ & $-2.898 * *$ & $-2.168 * * *$ & $-2.651 * * *$ & $1.449 * *$ & $3.094 * * *$ & 1.541 \\
\hline & $(-0.24)$ & $(-0.26)$ & $(-2.21)$ & $(-2.42)$ & $(-2.08)$ & $(-2.73)$ & $(-3.86)$ & $(2.28)$ & $(4.38)$ & $(1.20)$ \\
\hline \multirow[t]{2}{*}{ Foreign } & $0.0211 * * *$ & 0.0373 & $6.571 * * *$ & $12.56 * * *$ & $2.197 * * *$ & $1.104 * *$ & $0.696 * *$ & $-0.499 *$ & $-1.239 * * *$ & $-1.969 * * *$ \\
\hline & $(3.21)$ & (1.07) & $(2.63)$ & $(3.31)$ & $(2.87)$ & $(2.48)$ & $(2.32)$ & $(-1.68)$ & $(-3.77)$ & $(-2.86)$ \\
\hline \multirow[t]{2}{*}{ HHI } & $0.00205 * *$ & $0.0234 * * *$ & -0.157 & -0.620 & -0.141 & -0.0670 & $-0.153 * *$ & $0.142 * * *$ & $0.252 * * *$ & 0.0483 \\
\hline & $(2.40)$ & $(4.95)$ & $(-0.53)$ & $(-1.32)$ & $(-0.89)$ & $(-0.78)$ & $(-2.25)$ & $(2.79)$ & $(4.24)$ & $(0.37)$ \\
\hline \multirow[t]{2}{*}{ Covdep } & & & & & -0.0870 & -0.116 & $-0.109 *$ & 0.101 & $0.137 *$ & -0.0473 \\
\hline & & & & & $(-0.55)$ & $(-1.31)$ & $(-1.66)$ & $(1.54)$ & $(1.80)$ & $(-0.28)$ \\
\hline \multirow[t]{2}{*}{ Constant } & $-0.0964 * * *$ & $-0.636 * * *$ & $-13.75 * *$ & -12.22 & 0.370 & -2.086 & $2.925 * * *$ & -1.088 & -0.194 & -1.391 \\
\hline & $(-5.90)$ & $(-7.53)$ & $(-2.51)$ & $(-1.37)$ & $(0.15)$ & $(-1.44)$ & $(2.91)$ & $(-1.25)$ & $(-0.19)$ & $(-0.58)$ \\
\hline No. obs. & 682 & 671 & 682 & 681 & 596 & 563 & 583 & 681 & 680 & 670 \\
\hline F-stat. & 15.83 & 23.61 & 4.403 & 2.936 & 2.937 & 4.096 & 6.703 & 7.470 & 7.548 & 3.334 \\
\hline Hansen J-stat & 3.703 & 5.702 & 2.673 & 0.070 & 0.093 & 0.277 & 0.217 & 1.158 & 0.055 & 0.462 \\
\hline Endogoneity test & $11.659 * * *$ & $11.134 * * *$ & $34.720 * * *$ & $62.376 * * *$ & $51.89 * * *$ & $14.533 * * *$ & $7.630 * * *$ & $13.714 * * *$ & $17.577 * * *$ & $102.315 * * *$ \\
\hline
\end{tabular}

Table 7 the IV/2SLS estimation with robust adjustment for small samples by Windmeijer (2000). The dependent variables are performance (ROA, ROE, adj ROA, adj ROE) and risk (ADZP, ADZP1, ADZP2, SDROA, SDROE, NPL). Explanatory variables are family indirect control, political connection (PolCon), listed dummy ( $1=$ listed, zero otherwise), foreign bank dummy (1=foreign owned, zero otherwise), logarithm of total assets (Size), equity to total assets ratio (Capital), bank's income diversification (Diver), banking concentration index (HHI) and coverage of deposit insurance (Covdep). We also include dummy for the 2008 crisis period. Superscripts ***, **, and * denotes statistical significant at the .01, .05 and .10 levels respectively. t-statistics shown in parentheses are corrected for White heteroskedasticity. 
Appendix A

\begin{tabular}{ll}
\hline Variable & Description \\
\hline Panel A: Dependent & $\begin{array}{l}\text { variables } \\
\text { Return on total assets is net income divided by total assets }\end{array}$ \\
ROE & Return on total equity is net income divided by total equity \\
adjROA & $\begin{array}{l}\text { Return on assets divided by standard deviation of the last three } \\
\text { year for each respective year }\end{array}$ \\
adjROE & $\begin{array}{l}\text { Return on equity divided by standard deviation of the last three } \\
\text { year for each respective year }\end{array}$ \\
R-score (ADZP) & $\begin{array}{l}\text { Return on assets (ROA) plus equity to total assets ratio, divided by } \\
\text { the standard deviation of last three-year ROA }\end{array}$ \\
ADZP1 & $\begin{array}{l}\text { Average return on assets (ROA) divided by the standard deviation } \\
\text { of last three-year ROA } \\
\text { Average equity to total assets ratio, divided by the standard } \\
\text { deviation of last three-year ROA } \\
\text { Bank non performing loan is total non-performing loans divided } \\
\text { by total gross loans } \\
\text { Standard deviation of last three-year return on assets }\end{array}$ \\
NPL & $\begin{array}{l}\text { Standard deviation of last three-year return on equity } \\
\text { Std. Dev of ROA }\end{array}$
\end{tabular}

Panel B: Independent variables

Family Dummy variable that take 1 (one) if at least $10 \%$ of the bank ownership in any forms is controlled/owned by a family and zero otherwise.

Fam_direct

Dummy variable that take 1 (one) if the family including its individual members has total direct ownership at least $10 \%$, zero otherwise

Family_only

Dummy variable equal to 1 (one) if the family owns at least $10 \%$ of the bank without any other institutional shareholder holding at least $10 \%$ of the shares, zero otherwise

Family_with_inst Dummy variable equal to 1 (one) if the family owns at least $10 \%$ of the bank and there is an institutional shareholder holding at least $10 \%$ of the shares, zero otherwise

Fam director

Dummy variable equal to 1 (one) if the owning family appoints one of its members as the directors(s), zero otherwise

Fam

director_with_inst

Dummy variable equal to 1 (one) if the owning family appoints one of its members as the directors(s) and there is an institutional shareholder holding at least $10 \%$ of the shares, zero otherwise, zero otherwise

Fam_Indirect

Dummy variable that take 1 (one) when the family hold ownerships at least $10 \%$ of the shares through its affiliated firms, zero otherwise

PolCon

Dummy variable equals one (1) if the bank is a state-owned banks or private banks that at least one of their owners, directors, or commissioners (supervisory body) is a political party member, a parliament member, a government official, a former of parliament member and/ or a former of government official, and zero otherwise

Size

Income

Diversification

Logarithm of total assets

(Diver)

Source

Annual Reports, Bankscope

Annual Reports, Bankscope

Annual Reports, Bankscope

Annual Reports, Bankscope

Annual Reports, Bankscope

Annual Reports, Bankscope

Annual Reports, Bankscope

Annual Reports, Bankscope

Annual Reports, Bankscope

Annual Reports, Bankscope

Annual Reports, Indonesian Banks Association, News releases

Annual Reports, Indonesian Banks

Association, News releases

Annual Reports,

Indonesian Banks

Association, News releases

Annual Reports,

Indonesian Banks

Association, News releases

Annual Reports,

Indonesian Banks

Association, News releases

Annual Reports,

Indonesian Banks

Association, News releases

Annual Reports,

Indonesian Banks

Association, News releases

Annual Reports,

Indonesian Banks

Association, other sources, News releases

Annual Reports Annual Reports 
Capital

Herfindahl-

Hirschman Index

(HHI)

Foreign

Listed

Covdep
Total equity divided by total assets

Herfindahl-Hirschman index of banking concentration, as follows:

$\mathrm{HHI}=\frac{\sum_{\mathrm{i}=\mathrm{i}}^{\mathrm{m}} \mathrm{s}^{2}}{100}$, where $\mathrm{s}_{\mathrm{i}}$ is the percentage of bank- $i$ assets in the banking sector

Dummy that takes 1 (one) if there is foreign ownerships (Foreign) of $50 \%$ or more and zero otherwise

Dummy that equals 1 (one) if the bank is publicly listed and zero otherwise

The natural log value of (1+coverage deposits), where coverage deposits is the ratio of the maximum deposit insurance coverage limit per deposit per capita
Annual Reports

Annual Reports, Bank Indonesa

Annual Reports

Annual Reports

Authors'calculation based on the data from Demirgüç-Kunt et al. (2005), updated for Asia 